\title{
Myf5 haploinsufficiency reveals distinct cell fate potentials for adult skeletal muscle stem cells
}

\author{
Barbara Gayraud-Morel ${ }^{1}$, Fabrice Chrétien ${ }^{1,2, \star}$, Aurélie Jory ${ }^{1, *, \pm}$, Ramkumar Sambasivan ${ }^{1, \star}$, Elisa Negroni ${ }^{6}$, \\ Patricia Flamant, Guillaume Soubigou ${ }^{3}$, Jean-Yves Coppée ${ }^{3}$, James Di Santo ${ }^{4}$, Ana Cumano ${ }^{5}$, Vincent Mouly ${ }^{6}$ \\ and Shahragim Tajbakhsh ${ }^{1, \S}$
}

${ }^{1}$ Stem Cells and Development, Department of Developmental Biology, Institut Pasteur, CNRS URA 2578; ${ }^{2}$ Unité d'Histopathologie humaine et modèles animaux; ${ }^{3}$ Unité Transcriptome et Epigénome; ${ }^{4}$ Unité d'Immunité Innée; ${ }^{5}$ Unité du Développement des Lymphocytes, Institut Pasteur, 25 rue du Dr Roux, 75105 Paris, France

${ }^{6}$ Université Pierre et Marie Curie (Paris 6) UM76, INSERM UMRS974, CNRS UMR7215, Institut de Myologie, Groupe Hospitalier Pitié-Salpétrière, 47-83 bd de l'Hopital, 75651 Paris Cedex 13, France

${ }^{*}$ These authors contributed equally to this work

¥Present address: Columbia University Medical Center, 701 W168th Street, HHSC 1104, New York, NY 10032, USA

${ }^{\S}$ Author for correspondence (shaht@ @asteur.fr)

Accepted 18 November 2011

Journal of Cell Science 125, 1738-1749

(C) 2012. Published by The Company of Biologists Ltd

doi: $10.1242 / j c s .097006$

\section{Summary}

Skeletal muscle stem cell fate in adult mice is regulated by crucial transcription factors, including the determination genes $M y f 5$ and Myod. The precise role of Myf5 in regulating quiescent muscle stem cells has remained elusive. Here we show that most, but not all, quiescent satellite cells express Myf5 protein, but at varying levels, and that resident Myf5 heterozygous muscle stem cells are more primed for myogenic commitment compared with wild-type satellite cells. Paradoxically however, heterotypic transplantation of Myf5 heterozygous cells into regenerating muscles results in higher self-renewal capacity compared with wild-type stem cells, whereas myofibre regenerative capacity is not altered. By contrast, $\operatorname{Pax} 7$ haploinsufficiency does not show major modifications by transcriptome analysis. These observations provide a mechanism linking Myf5 levels to muscle stem cell heterogeneity and fate by exposing two distinct and opposing phenotypes associated with Myf5 haploinsufficiency. These findings have important implications for how stem cell fates can be modulated by crucial transcription factors while generating a pool of responsive heterogeneous cells.

Key words: Satellite cell, Myogenic regulatory factors, Myf5, Pax7, Regeneration, Stem cell, Heterogeneity, Transcriptional priming, Haploinsufficiency

\section{Introduction}

Vertebrate organogenesis, growth and regeneration rely on tissuespecific stem cell populations that generate committed precursors and differentiated cells while maintaining a reservoir of stem cells for long-term tissue maintenance in the adult. Distinguishing how these decisions are balanced is a major topic of interest in stem cell biology. Recent studies have suggested that some tissues might harbour multiple stem cell entities, or stem cells with distinct states of commitment and potential (Li and Clevers, 2010; Lugert et al., 2010; Mitchell et al., 2010; Tajbakhsh, 2009). It has been proposed also that in the blood, intestine and hair follicle lineages, a more engaged stem cell population could serve to function in routine repair, whereas a more primitive, infrequently dividing fraction might assure progeny, stem and committed cells for longer periods (Li and Clevers, 2010; Wilson et al., 2008).

Adult skeletal muscle stem (satellite) cells, reside between the myofibre plasmalemma and the surrounding basement membrane, and they are in a reversible quiescent state. They enter the cell cycle after muscle injury to produce myoblasts that fuse to the existing myofibres, or generate de novo myofibres to effect tissue repair. Muscle stem cell self-renewal and commitment are controlled by a genetic network of transcription factors including the paired-box homeodomain proteins Pax3 and Pax7, and basic helix-loop-helix muscle regulatory factors (MRFs), Myf5, Mrf4,
Myod and myogenin (Kassar-Duchossoy et al., 2004; Relaix et al., 2005; Rudnicki et al., 1993; Tajbakhsh et al., 1997). Myf5, Mrf4 and Myod act as the obligate determinants for the acquisition of myogenic cell fate (Kassar-Duchossoy et al., 2004; Rudnicki et al., 1993), whereas myogenin functions as a differentiation factor (Hasty et al., 1993; Nabeshima et al., 1993). Unlike Pax3, which is downregulated in most muscles from fetal stages, $\operatorname{Pax} 7$ expression marks stem and progenitor cells from the early embryo to adult satellite cells; hence it is currently the most reliable marker for satellite cells (Bosnakovski et al., 2008; Relaix et al., 2006; Seale et al., 2000). In addition, mice null for $\operatorname{Pax} 7$ have no overt deficits in myogenesis prenatally, but they are severely deficient in muscle satellite cells after birth (Kuang et al., 2006; Oustanina et al., 2004; Relaix et al., 2006; Seale et al., 2000). Notably however, Pax3:Pax 7 conditional double mutants do not compromise adult satellite cell self-renewal and differentiation, therefore, it remains unclear which genes regulate adult muscle satellite cell selfrenewal and fate (Lepper et al., 2009).

Other markers of satellite cells include the $M y f 5^{\text {nlac } Z}$ mouse, and the cell surface markers M-cadherin, syndecan-3 and syndecan-4, CD34, $\alpha 7$ integrin, CXCR4 and SM/C2.6 antigen (Vcam) (Beauchamp et al., 2000; Cerletti et al., 2008; Cornelison et al., 2004; Fukada et al., 2007; Gnocchi et al., 2009; Kuang and Rudnicki, 2008). Although Myod protein is expressed in a minor 
fraction of quiescent satellite cells, a hallmark for activated satellite cells is the robust expression of this protein before the first cell division (Kanisicak et al., 2009; Zammit et al., 2002). Systematic detection of Myf5 protein in quiescent and freshly activated satellite cells has been less clear (Beauchamp et al., 2000; Day et al., 2010; Dhawan and Rando, 2005; Gayraud-Morel et al., 2007; Gayraud-Morel et al., 2009; Zammit et al., 2006). Pax7 expression declines during myogenic commitment, but it is maintained in self-renewing satellite cells, which also lose Myod protein expression (Dhawan and Rando, 2005; Zammit et al., 2004; Zammit et al., 2006).

Heterogeneity among adult muscle stem cells has been suggested by results from different experimental approaches. For example, satellite cells have different developmental origins and consequently, those found in the head have distinct molecular signatures that reflect in part their developmental ontology (Harel et al., 2009; Sambasivan et al., 2009). In vitro heterogeneity of satellite cells was illustrated by their different clonal sizes and capacity to differentiate into myotubes (Cooper et al., 1999; Day et al., 2010; Lagord et al., 1998; Ono et al., 2010). Other studies reported that some, but not all, satellite cells (7-50\%) perform biased DNA segregation during mitosis where one daughter cell inherits older template strands and the other daughter cell newly replicated DNA strands (Conboy et al., 2007; Shinin et al., 2006, Rocheteau et al., 2012). Although the precise reason for this phenomenon remains unclear (Tajbakhsh and Gonzalez, 2009), it underscores a phenotypic difference among satellite cells that might have functional consequences. In other studies, Syndecan4, Sca1, Abcg2, (3\% satellite cells) (Tanaka et al., 2009) or CXCR4 (80\% satellite cells) (Cerletti et al., 2008) were used as markers to distinguish satellite cell subpopulations with reported differences in engraftment potential.

Using Myf5 $5^{C r e}$ crossed with a Rosa ${ }^{\text {Stop-YFP }}$ reporter mouse, a subset of postnatal Pax7-expressing satellite cells were found to be YFP $^{-}$(about $10 \%$ ) suggesting that they were less committed (Kuang et al., 2007). Functional transplantation studies into Pax7-null muscle suggested that $\mathrm{YFP}^{-}$cells have a reduced tendency to form myofibres but a greater capacity to replenish the stem cell niche compared with cells historically expressing Myf5 (Kuang et al., 2007). Another study showed that YFP ${ }^{-}$cells were enriched for mRNA encoding the receptor Tie2, which has been shown to promote cellular quiescence (Abou-Khalil et al., 2009). By contrast, when Myod ${ }^{\text {Cre }}$ mice were crossed with Rosa ${ }^{\text {Stop-YFP }}$ reporter mice, virtually no $\mathrm{YFP}^{-}$stem cells were observed (Kanisicak et al., 2009). Thus some genetic tools have exposed heterogeneities among muscle stem cells, yet the functional consequences of these differences remain unclear.

Collectively, these studies have prompted a closer examination of the skeletal muscle stem cell population to understand the nature of the heterogeneity, and whether their potential can be revealed functionally during tissue repair. Reconciling the reported differences in stem cell properties as well as their biological relevance can provide important insights in how cell fate in this paradigmatic stem cell population is regulated. Here, we show that although heterozygous $\mathrm{Myf5}^{+}$satellite cells are transcriptionally primed for commitment, they regenerate skeletal muscle and replenish the satellite cell niche more efficiently than wild-type satellite cells after transplantation. This differential effect was not observed with heterozygous $\operatorname{Pax} 7$ stem cells. These findings underscore the importance of using different phenotypic readouts to identify distinct stem cell states, and they provide insights into how Myf5 acts as a modulator of muscle stem cell fate.

\section{Results}

\section{Expression of Myf5 protein in quiescent satellite cells}

Our previous studies, and those from other laboratories, showed that the majority ( $\sim 90 \%)$, but not all, satellite cells are labelled in Myf5 $5^{\text {nlacZ/+ }}$ mice (Beauchamp et al., 2000; Day et al., 2010; Zammit et al., 2002). It remains unclear whether genetic reporters, which are relatively stable compared with transcription factors, reflect endogenous Myf5 protein levels, an important point in assessing the myogenic commitment state of muscle stem cells. Furthermore, the expression of Myf5 protein has not been systematically assessed in quiescent and activated satellite cells, due in part to difficulties in using antibodies against Myf5; hence the role of this protein in quiescent satellite cells remains poorly defined.

To investigate the quiescent satellite cell population, we used two different $\operatorname{Pax} 7$ reporter mice: transgenic $T g: P a x 7-n G F P$ mice (Sambasivan et al., 2009) and knock-in mice $P a x 7^{n G F P /+}$ Immunostaining of satellite cells with antibodies against Pax7 and GFP on freshly isolated extensor digitorium longus (EDL) fibres showed $100 \%$ co-expression between endogenous Pax7 protein and the $n G F P$ reporter for both $T g: P a x 7-n G F P$ and $P a x 7^{n G F P /+}$ mice (Sambasivan et al., 2009) (Fig. 1A). This was also the case for satellite cells on sections of Tibialis anterior (TA) muscle (supplementary material Fig. S1A). Isolated single myofibres can be cultured in suspension for several days and this paradigm permits the monitoring of distinct cell states from the quiescent muscle stem cell, to the generation of myoblasts, and finally self-renewal or commitment cell fates in the absence of cell fusion with the myofibre (Zammit et al., 2004). To validate our findings, this model and directly cultured primary myogenic cells were evaluated. In experiments with floating myofibres at 72 hours, and with 1 week cultured myoblasts, we found that the $n G F P$ reporter from $T g: P a x 7-n G F P$ mice faithfully reproduced endogenous $\operatorname{Pax} 7$ expression (supplementary material Fig. S1B,C). GFP expression was essentially absent, or weakly expressed, in differentiated myogenin ${ }^{+}$cells and absent in myonuclei (supplementary material Fig. S1B,C). Isolation of satellite cells by FACS from Tg:Pax7-nGFP mice showed that they were phenotypically small in size and exhibited low cellular granulosity, as previously reported for satellite cells isolated using other markers (Fig. 1A) (Bosnakovski et al., 2008; Kuang et al., 2007; Montarras et al., 2005). Under our gating conditions, $\operatorname{Pax} 7^{+}$cells represented about $2 \%$ of all mononucleated cells from fore- and hindlimb muscle extracts. In general, $5 \times 10^{5}-10 \times 10^{5}$ quiescent satellite cells were isolated from $\mathrm{Tg}: \operatorname{Pax} 7-n G F P$ foreand hindlimbs.

Immunolabelling followed by FACS showed that $\operatorname{Pax} 7^{n G F P /+}$ and Tg:Pax7-nGFP populations were negative for CD45, CD31 and Sca1, but positive for CD34 and $\alpha 7$ integrin, as shown previously for freshly isolated satellite cells (supplementary material Fig. S2A) (Bosnakovski et al., 2008; Cerletti et al., 2008; Joe et al., 2010; Montarras et al., 2005). To investigate the purity and myogenic potential of these populations, $\mathrm{GFP}^{+}$cells were isolated, plated overnight and stained with antibodies against Pax7 and Myod. All GFP ${ }^{+}$cells were positive for Pax7 and/or Myod ( $n=100$ cells, $n=3$ animals for each model; data not shown). Purity and myogenicity of $\mathrm{GFP}^{+}$cells were tested further by clonal analysis of single cells in 96-well plates. After 1 week 

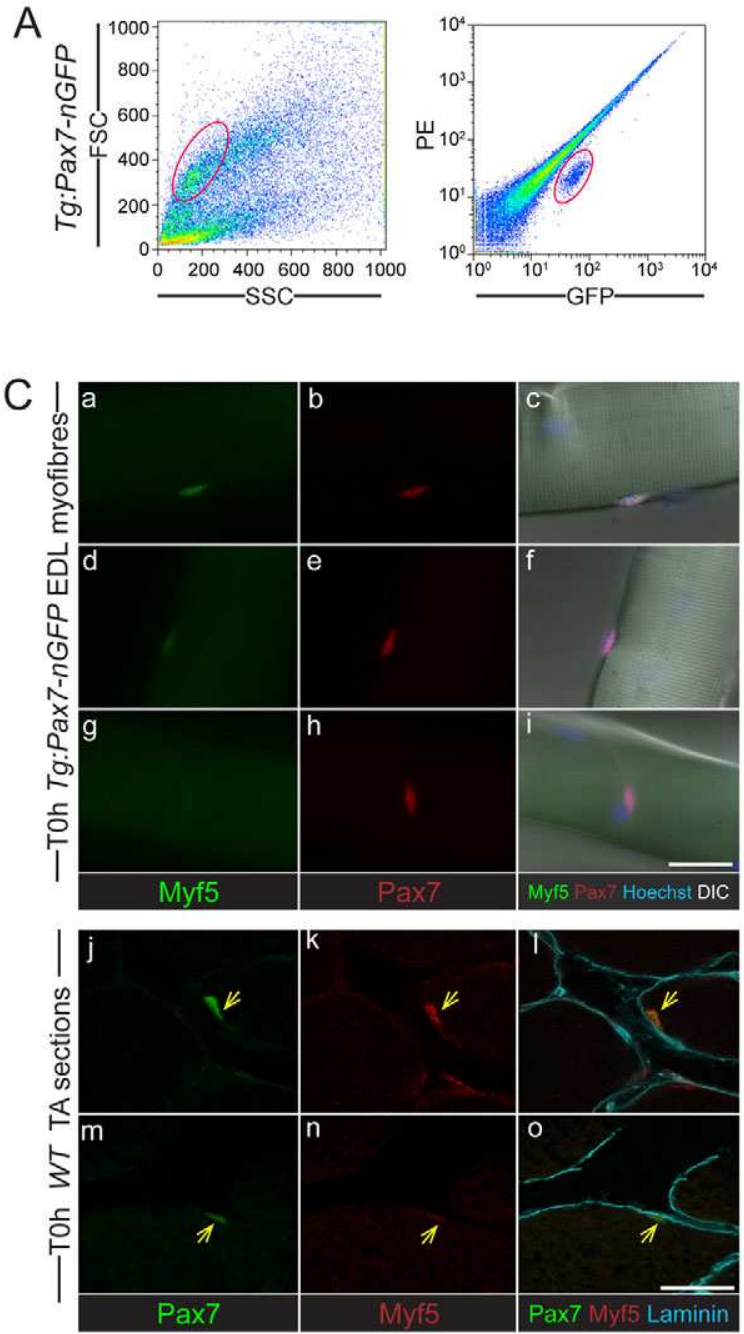

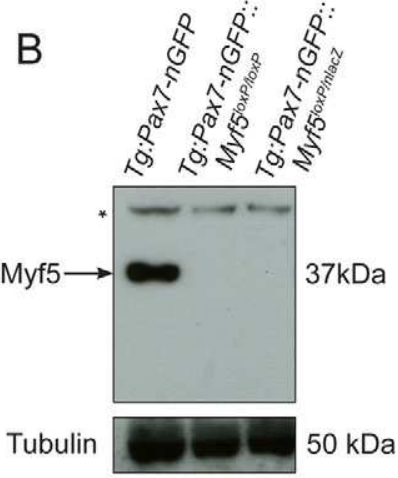

D

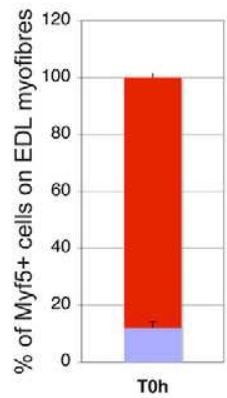

- $\mathrm{Pax} 7^{+} \mathrm{Myf5}^{+}$ $=\mathrm{Pax}^{+}$Myf5-

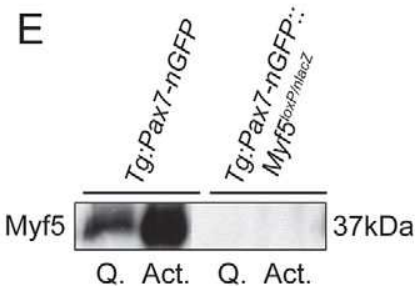

Fig. 1. Myf5 protein is expressed in adult quiescent satellite cells. (A) FACS profiles of freshly isolated $\mathrm{GFP}^{+}$satellite cells from $\mathrm{Tg}$ :Pax7$n G F P$ skeletal muscles. $\mathrm{GFP}^{+}$cells correspond to a low granulosity (low side-scatter; SSC), small size cell (low forward scatter; FSC) population. $Y$ axis on left panel is uncompensated red fluorescence; PE, phycoerythrin, 594 channel. (B) Western blot of FACS-isolated quiescent $\mathrm{GFP}^{+}$satellite cells from control Tg:Pax7-nGFP and Myf5-null mice, Tg:Pax7-nGFP:Myf $5^{\text {loxP/loxP }}$ and Tg:Pax7-nGFP:Myf5 $5^{\text {loxP/nlacZ }}$. Satellite cells from Tg:Pax $7-n G F P$ show a $37 \mathrm{kDa}$ band for Myf5 protein; note its absence in Myf5 mutants. Asterisk denotes nonspecific band (GayraudMorel et al., 2007). (C) (a-i) Immunostaining on freshly isolated (T0h) $T g: P a x 7-n G F P$ EDL myofibres. Note heterogeneous Myf5 protein expression in $\mathrm{Pax} 7^{+}$population. Examples of robust $(\mathrm{a}-\mathrm{c})$, faint $(\mathrm{d}-\mathrm{f})$ or negative $(\mathrm{g}-\mathrm{i})$ staining obtained with Myf5 antibodies. (j-o)

Immunostaining on wild-type TA frozen sections with anti-Myf5, Pax7 and laminin antibodies shows a high ( $\mathrm{j}-1)$ and a low (m-o) Myf5 expressing cell (arrows). (D) Quantification of $\mathrm{Myf5}^{+}$cells within $\mathrm{Pax}^{+}$satellite cells on Tg:Pax 7- $n$ GFP EDL myofibres at T0h $(n=3$ mice). (E) Western blot of quiescent and cultured (3 days) satellite cells. Myf5 is present in quiescent (Q.) satellite cells and upregulated in activated myoblasts (Act.). Results are mean \pm s.e.m. Scale bars: $20 \mu \mathrm{m}(\mathrm{C})$. in culture, clones varied in size, and they all expressed Myod and/ or myogenin, with some cells undergoing fusion at this stage (supplementary material Fig. S2B). Therefore, $\operatorname{Pax} 7^{n G F P /+}$ and Tg:Pax7-nGFP faithfully recapitulate $\operatorname{Pax} 7$ expression in quiescent satellite cells and they permit the isolation of highly pure muscle stem cells.

Given that only satellite cells are $\mathrm{GFP}^{+}$in skeletal muscles of Tg:Pax 7-nGFP adult muscle, quiescent satellite cells were isolated by FACS and examined by western blot for Myf5 protein. Robust expression of Myf5 was observed, and this expression was specific because Myf5-null satellite cells isolated by FACS from $\mathrm{Tg}: \mathrm{Pax} 7-$ $n G F P:: M y f 5^{\text {loxP/loxP }}$ or Tg:Pax7-nGFP ::Myf $5^{\text {loxP/lac } Z}$ were negative for this protein (Fig. 1B). The specificity of the antibody was confirmed further by immunostaining control and Myf5-null cryosections (supplementary material Fig. S3A). Interestingly, immunostaining showed that the level of expression varied in individual wild-type cells either on single myofibres (Fig. $1 \mathrm{Ca}-\mathrm{i}$ ) or frozen tissue sections (Fig. $1 \mathrm{Cj}-\mathrm{O}$ ). Quantification revealed that the majority of satellite cells expressed Myf5 protein (Fig. 1D; $n=4$ mice, 12-24 myofibres per mouse). A significant upregulation was observed in myoblasts after satellite cell activation and proliferation (Fig. 1E). As expected, Myf5 protein expression was downregulated during myogenic differentiation (supplementary material Fig. S3B, myogenin ${ }^{+}$cells).

\section{Myf5 heterozygous muscle stem cells are transcriptionally primed for commitment}

The varied expression of Myf5 protein suggested that this might be related to the heterogeneous behaviour of satellite cells. To determine the functional role of Myf5, mice with one compromised allele of Myf5 were examined using several approaches. Western blot analysis showed that $M y f 5^{l o x P /+}$ and $M y f 5^{G F P-P /+}$ satellite cells, whether taken as the entire cell population, or a subpopulation based on GFP positivity, expressed approximately half of the levels of Myf5 protein compared with levels in wild-type satellite cells (Fig. 2A,B). This suggests that no significant mono-allelic or cross-allelic regulation of the two Myf5 alleles takes place in Myf5 heterozygous mice.

Because $M y f 5$ acts as a determination gene in embryonic muscle progenitors, we reasoned that in the adult, Myf5 heterozygous satellite cells would be less committed. To test this notion, we performed quantitative reverse transcriptase PCR (RT-qPCR) for several markers specific to quiescence, activation or differentiation of total quiescent $M y f 5$ heterozygous satellite cells isolated by FACS. Unexpectedly, using $\operatorname{Tg}: P a x 7-n G F P^{+}$ mice in comparison to the total wild-type population, significantly higher levels of Myod and Myog transcripts were observed in Tg:Pax7-nGFP:Myf $5^{\text {loxP/+ }}$ cells (Fig. 2C). This committed status was underscored further by the increased 
A

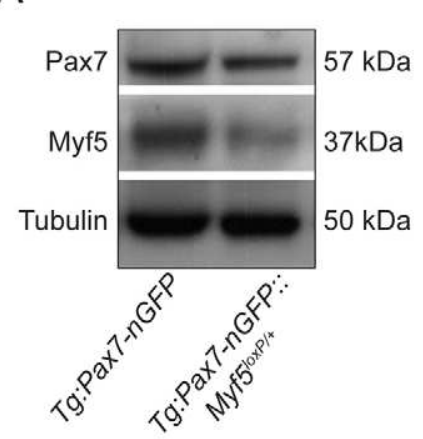

B

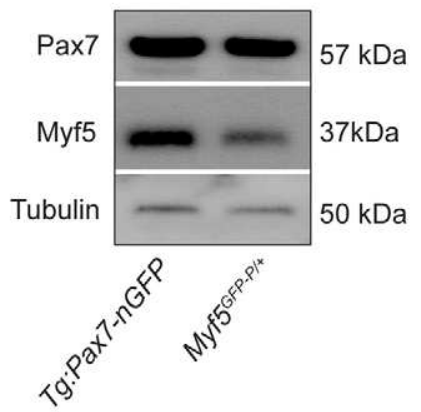

$\mathrm{E}$

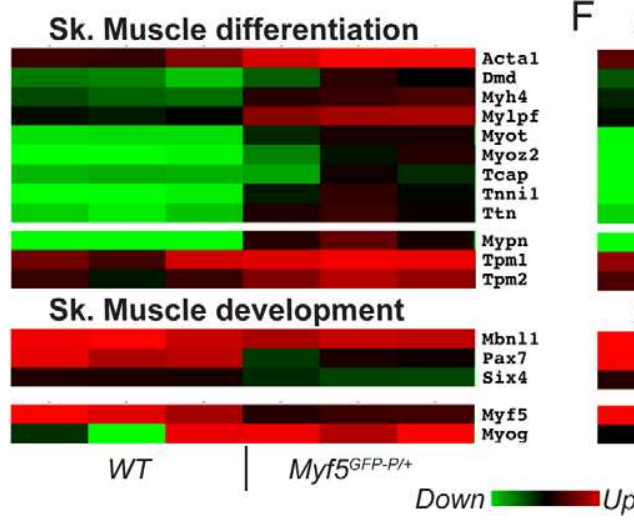

D
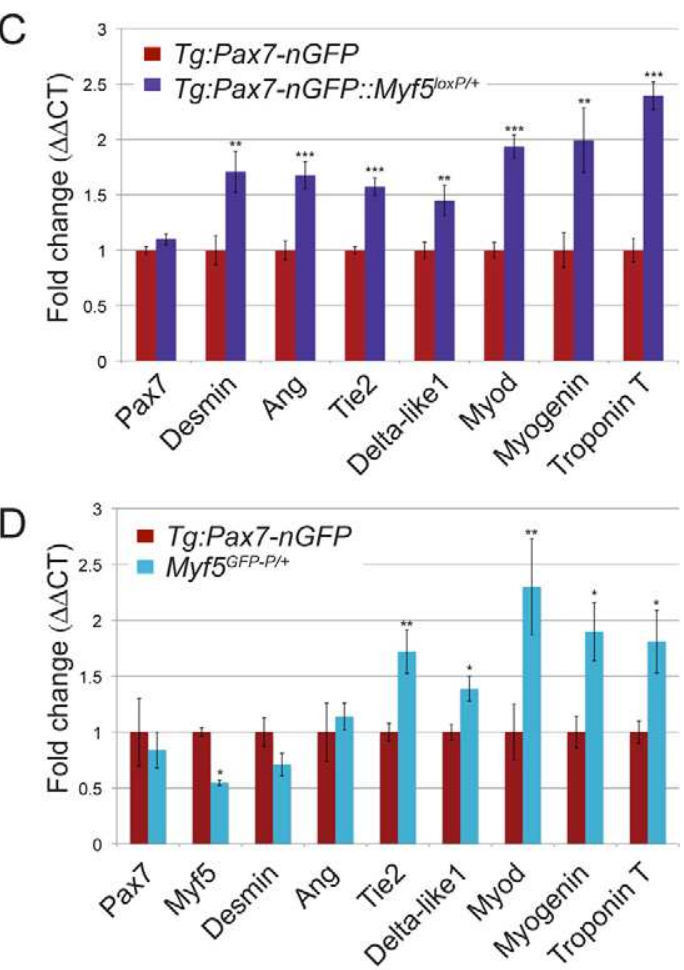

F Sk. Muscle differentiation

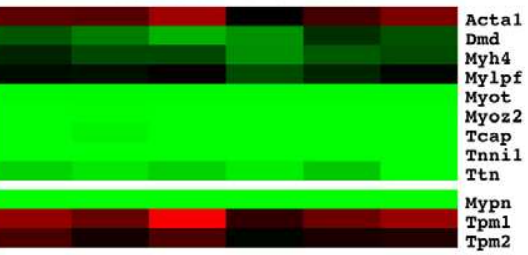

Sk. Muscle development

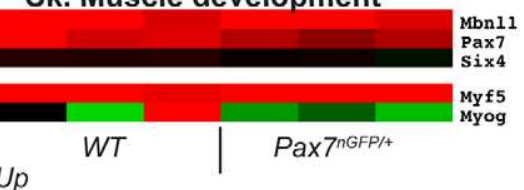

Fig. 2. Myf5 heterozygous satellite cells are primed for myogenic commitment. (A) Western blot with Tg:Pax7-nGFP:Myf5 $5^{\operatorname{lox} P /+}$ and Tg:Pax7$n G F P, \mathrm{GFP}^{+}$sorted satellite cells. Note reduced Myf5 protein levels in heterozygous quiescent satellite cells. (B) Western blot with $M y f 5^{G F P-P /+}$ and Tg:Pax7-nGFP, $\mathrm{GFP}^{+}$sorted satellite cells. Expression of Myf5 protein is reduced in heterozygous quiescent satellite cells. (C) Quantitative real-time RT-PCR. Results are expressed as a fold change $(\Delta \Delta \mathrm{CT})$ between $\mathrm{GFP}^{+}$ sorted cells from $\operatorname{Tg}: P a x 7-n G F P:: M y 5^{\text {loxP/+ }}$ and Tg:Pax7-nGFP ( $n=5$ mice). (D) Quantitative realtime RT-PCR. Results are expressed as fold change $(\triangle \Delta \mathrm{CT})$ between $\mathrm{GFP}^{+}$sorted cells from Myf5 $5^{G F P-P /+}$ and $T g: P a x 7-n G F P$. (n) values for RT-qPCR represent number of animals from $T g$ :Pax7 $-n G F P$ and $M y f 5^{G F P-P /+}$ mouse, respectively: Myf $5(n=10$; 8), Myod ( $n=4 ; 4), \operatorname{Myog}(n=10 ; 8), \operatorname{Pax} 7(n=4 ; 4)$, $\operatorname{TnT}(n=8 ; 7)$, Dll1 $(n=7 ; 4)$, Des $(n=13 ; 5)$, Tie 2 $(n=8 ; 7)$, Angl $(n=8 ; 7)$. (E) Gene expression profiles of WT (from $T g: P a x 7-n G F P$ ) and $M y f 5^{G F P-P /+}$. Heat map from Affimetrix GeneChip microarray analysis showing a cluster of genes involved in skeletal muscle contractile properties enriched in $M y f 5$ heterozygous cells $\left(M y f 5^{G F P-P /+}\right)$ compared with control (Tg:Pax7-nGFP). (F) Gene expression profiles of WT (from Tg:Pax7-nGFP) and $\operatorname{Pax} 7^{n G F P /+}$ quiescent satellite cells. Note only minor differences between gene expression profiles of control cells (Tg:Pax7-nGFP) and the heterozygous $P a x 7^{n G F P /+}$ cells. Results are mean \pm s.e.m. $* P<0.05, * * P<0.01, * * * P<0.001$. level of mRNA encoding the structural protein of mature skeletal muscle, Troponin-T, a protein that is expressed well downstream in this lineage, in differentiated cells. Satellite-cellderived myoblasts were reported to express high levels of members of the Notch-Delta signalling pathway for myoblast proliferation before differentiation (Conboy et al., 2003; Sun et al., 2008; Waddell et al., 2010). Consistent with the notion that Myf5 heterozygous cells are more committed, we noted higher expression levels of the Delta-like1 ligand, which marks committed myogenic cells (Delfini et al., 2000; Kuang et al., 2007; Schuster-Gossler et al., 2007; Waddell et al., 2010). Pax7, which is expressed in quiescent and activated myogenic cells, did not show any notable difference in expression. Interestingly, angiopoietin and its receptor Tie2, which are involved in satellite cell self-renewal, were both increased in Myf5 heterozygous cells. These findings were largely confirmed when a subpopulation of heterozygous satellite cells, marked by GFP expression from $M y f 5^{G F P-P /+}$ mice, was examined (Fig. 2D).
To validate and extend these findings, we performed Affimetrix GeneChip Microarrays of satellite cells from hind- and forelimb skeletal muscles (Fig. 2E). Several genes involved in the myofibre contractility machinery were upregulated in a heterozygous $M y f 5^{G F P-P /+}$ subpopulation of quiescent satellite cells, such as skeletal actin (Acta1, 3.7-fold), dystrophin (Dmd, 2.5 fold), isoforms of myosin heavy and light chains (Myh4, Mylpf, 3-fold and 3.5-fold, respectively), troponin I (Tnnil, 5.1-fold), tropomyosin (Tpm1, 2-fold) and titin (Ttn, 4.7-fold). Accordingly, Myog expression was upregulated in these cells. A similar transcriptome analysis carried out between $\operatorname{Pax} 7$ heterozygous satellite cells from $\operatorname{Pax} 7^{n G F P /+}$ knock-in mice and wild-type satellite cells showed no significant variations in gene expression between the two populations (Fig. 2F), indicating that unlike Myf5, haploinsufficiency of $\operatorname{Pax} 7$ does not alter the transcriptional priming state of satellite cells. Taken together, these findings indicate that quiescent muscle stem cells are sensitive to Myf5 expression levels, and that Myf5 heterozygous satellite cells are more transcriptionally primed for myogenic commitment. 


\section{Transplanted Myf5 heterozygous and wild-type satellite} cells have equivalent regenerative potentials

To determine whether the molecular signatures of cell commitment observed in Myf5 heterozygous quiescent satellite cells have functional consequences, we performed transplantation experiments with all cells or a subpopulation of quiescent satellite cells heterozygous for Myf5. To collect all satellite cells Tg:Pax7-nGFP were crossed with $M y f 5^{G F P-P /+}$ mice. Unlike Tg:Pax7-nGFP mice, which express a nuclear GFP, the $M y f 5^{G F P-P}$ expresses a brighter cytoplasmic GFP (Fig. 3A) (Kassar-Duchossoy et al., 2004; Sambasivan et al., 2009). Consequently, two GFP populations could be distinguished on the FACS profiles of satellite cells from simple (Fig. 3A) and compound crosses (Fig. 3B). Myf $5^{G F P-P /+}$ EDL myofibres contain an expected average number of about 10 satellite cells per EDL myofibre and therefore Myf5 heterozygosity does not appear to affect satellite cell numbers as is the case also with Myf $5^{\text {nlacZ/+ }}$ mice (Gayraud-Morel et al., 2007). However, only a subset (up to $20 \%$ ) of $\mathrm{Pax}^{+}$satellite cells co-expressed this GFP reporter (Fig. 3Ca-f), and this was not notably improved by removal of the puromycin resistance cassette (data not shown). This is consistent with fewer fluorescent cells obtained by FACS $(0.2$ to $0.4 \%)$ from $M y f 5^{G F P-P /+}$ limb muscles and a reduced number of $\mathrm{GFP}^{+}$cells counted per EDL myofibre (Fig. 3A,C) compared with that obtained from control mice.

For the transplantation experiments, two additional transgenic mice were used to follow the fate of the transplanted cells in vivo: (1) $T g: C A G-h P L A P$ carrying the human placental alkaline phosphatase gene which is expressed ubiquitously (DePrimo et al., 1996); and (2) Tg:MLC3F-nlacZ-2E, which marks
A

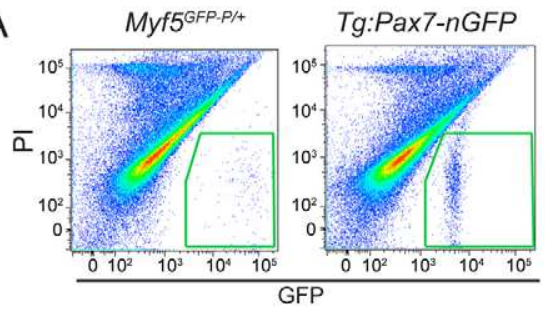

C
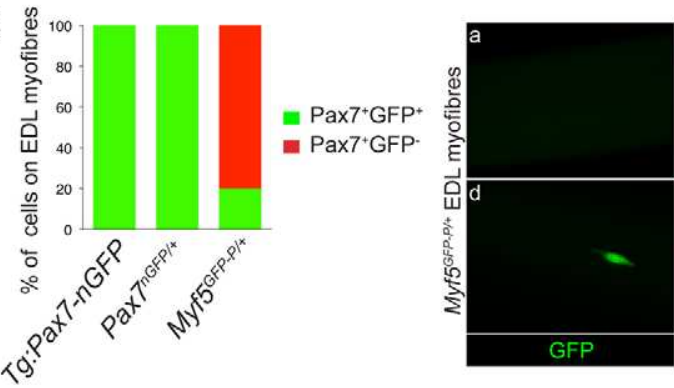

D

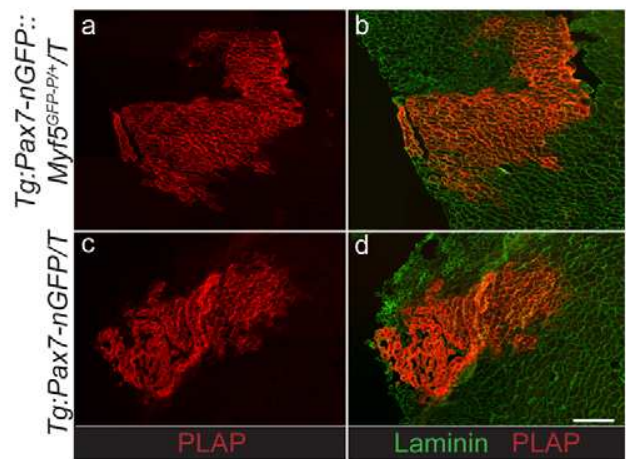

$\mathrm{F}$

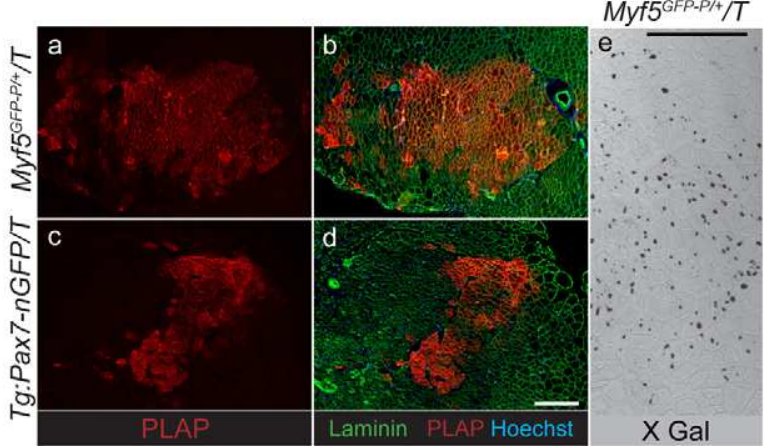

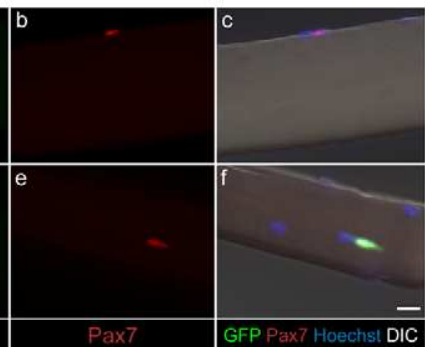

B Tg:Pax7nGFP::Myf5GFP.P/+
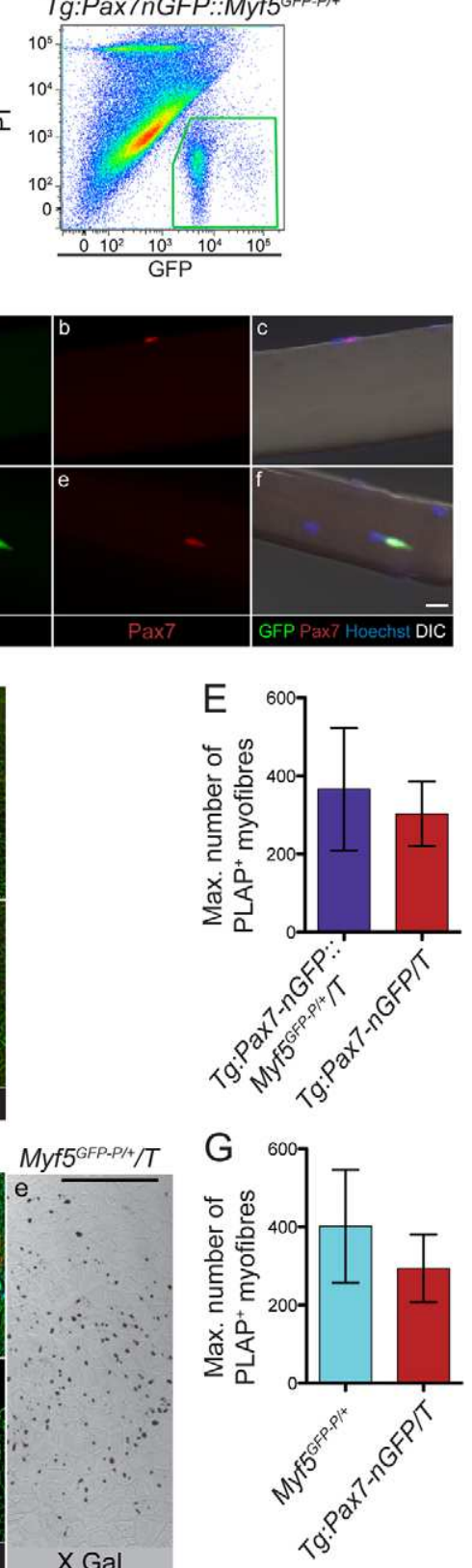

Fig. 3. Equivalent regenerative capacity of transplanted $M y f 5$ heterozygous satellite cells. $(\mathbf{A}, \mathbf{B})$ FACS profile of satellite cells from $M y f 5^{G F P-P /+}$ or Tg:Pax7-nGFP (A) and compound Tg:Pax7$n G F P:: M y f 5^{G F P-P /+}$ (B) mouse skeletal muscles. (C) Quantification and immunostaining for Pax7 and GFP on EDL myofibres (T0h). In Tg:Pax $7-n G F P$ and $\operatorname{Pax} 7^{n G F P /+}$ mice all $\mathrm{Pax} 7^{+}$satellite cells are $\mathrm{GFP}^{+}$. In $M y f 5^{G F P-P /+}$ the majority of $\mathrm{Pax} 7^{+}$satellite cells are $\mathrm{GFP}^{-}$(a-c), only $10-20 \%$ of Pax $7^{+}$cells co-express GFP (d-f). (D) Cryodamaged Rag2 ${ }^{-/}: \gamma \mathrm{C}^{-/}$mice were transplanted with $10^{4}$ freshly sorted satellite cells and analysed after 4 weeks. Representative area of $T g$ :Pax7$n G F P: M y f 5^{G F P-P /+} / T$ and $T g: P a x 7-n G F P / T$ donorderived PLAP $^{+}$myofibres stained with anti-laminin antibody to outline the basement membrane.

(E) Average number of PLAP ${ }^{+}$myofibres from $T g: P a x 7-n G F P: M y f 5^{G F P-P /+} / T$ ( $n=4$ recipient mice) and Tg:Pax7-nGFP/T ( $n=4$ recipient mice). Equivalent myofibre regeneration was noted $(P>0.05)$. (F) (a-d) Representative areas of $M y f 5^{G F P-P /+} / T$ and $T g: P a x 7-$ $n G F P / T$ donor derived PLAP ${ }^{+}$myofibres stained with anti-laminin antibody to outline the basement membrane. (e) Myonuclei generated from the transplanted cells are detected by X-gal ${ }^{+}$staining. (G) Average number of $\mathrm{PLAP}^{+}$myofibres from $M y f 5^{G F P-P /+} / T(n=4$ recipient mice) and Tg:Pax7$n G F P / T$ ( $n=4$ recipient mice). Equivalent myofibre regeneration was noted $(P>0.05)$. Results are mean \pm s.e.m. Scale bars: $10 \mu \mathrm{m}(\mathrm{C}), 300 \mu \mathrm{m}(\mathrm{D}, \mathrm{F})$. 
differentiated myonuclei (Kelly et al., 1995). Therefore, triple (T) or quadruple genetically modified mice were generated for the transplantations: Tg:Pax 7-nGFP::Myf ${ }^{\text {GFP-P/+ }}:: T g: h P L A P:: T g: 3 F-$ nlacZ-2E (hereafter called Tg:Pax7-nGFP::Myf5 $5^{G F P-P /+} / T$ ), Tg:Pax 7-nGFP::Tg:hPLAP ::Tg:3F-nlacZ-2E (hereafter called Tg:Pax $7-n G F P / T)$.

For the functional assays, $10^{4}$ freshly isolated $\mathrm{GFP}^{+}$cells were transplanted into the TA muscle of $\operatorname{Rag}^{-1-}: \mathrm{C}^{-1}$ immunocompromised recipient mice (Colucci et al., 1999) where the muscle was previously injured by cryodamage (SilvaBarbosa et al., 2005). PLAP ${ }^{+}$myofibres were enumerated by immunostaining in combination with anti-laminin antibody, which outlines the surrounding basement membrane of each myofibre (Fig. 3D). The majority of myogenic cells localised close to the site of injection, as reported previously (Schultz et al., 1988). Although the number of $\mathrm{PLAP}^{+}$myofibres generated from engrafted cells varied (from 40-700) between host animals as reported previously (Collins et al., 2005), individual animals responded similarly for the Tg:Pax 7-nGFP::Myf5 $5^{G F P-P /+} / T$ and Tg:Pax $7-n G F P / T$ engrafted populations. On average, Tg:Pax7-nGFP::Myf5 $5^{G F P-P /+} / T$ and Tg:Pax7-nGFP/T satellite cells generated 366 and 300 PLAP $^{+}$ myofibres respectively (Fig. $3 \mathrm{E} ; n=4$ animals, $P>0.05$ ). These findings show that $M y f 5$ heterozygous and wild-type satellite cells contributed equivalently to regenerating myofibres.

Similar results were obtained with the subpopulation of $M y f 5$ heterozygous satellite cells isolated from $M y f 5^{G F P-P /+} / T$. The myogenic specificity of these cells was also evaluated by FACS and clonal analysis as described above for Tg:Pax7-nGFP mice (supplementary material Fig. S2A,B). The number of PLAP ${ }^{+}$ myofibres generated from engrafted cells varied (from 20 to 700 ), yet individual animals responded similarly for the $M y f 5^{G F P-P /+} / T$ subpopulation compared with the total Tg:Pax7-nGFP/Tengrafted population (Fig. 3F). On average, $M y f 5^{G F P-P /+} / T$ and Tg:Pax7-nGFP/T satellite cells generated 400 and 300 PLAP $^{+}$ myofibres, respectively (Fig. $3 \mathrm{G} ; n=4$ animals, $P>0.05$ ). Four weeks after transplantation, cross sections of muscle contained centrally located X-gal ${ }^{+}$myonuclei and large clusters of PLAP ${ }^{+}$ regenerating myofibres (Fig. $3 \mathrm{Fe}$ ). Therefore, using either the total Myf5 heterozygous cells, or a subpopulation, we found no significant difference in myofibre contribution compared with wild-type satellite cells.

\section{Higher self-renewal capacity of Myf5 heterozygous compared with wild-type muscle stem cells}

As regeneration is completed and muscle homeostasis is reestablished, the skeletal muscle niche is replenished with new quiescent muscle stem cells. Self-renewal of satellite cells was assayed for Tg:Pax7-nGFP::Myf5 $5^{G F P-P /+} / T$ (Fig. 4A) or $M y f 5^{G F P-P /+} / T$ (Fig. 4B) mice to investigate the effect of $M y f 5$ haploinsufficiency on stem cell behaviour. Engrafted satellite cells that were located under the basement membrane were positive for Pax7 staining (Fig. 4Bd,i) and were scored as $\mathrm{GFP}^{+}$ and $\mathrm{PLAP}^{+}$(Fig. 4A,B). Only rare $\mathrm{GFP}^{+}$satellite cells were found associated with PLAP $^{-}$myofibres, in keeping with our findings above that the transplanted satellite cells did not disperse extensively. Quantification showed that, unexpectedly, a higher number of $\mathrm{GFP}^{+}$cells was associated with newly formed myofibres for Myf5 heterozygous satellite cells (Tg:Pax7$n G F P:: M y f 5^{G F P-P /+} / T$ donors) compared with wild-type cells (Tg:Pax 7-nGFP/T donors) (Fig. 4C; $P<0.001$ ).
Similarly, quantification of $\mathrm{GFP}^{+} / \mathrm{PLAP}^{+}$satellite cells engrafted from $M y f 5^{G F P-P /+} / T$ mice (Fig. 4B), where only the $\mathrm{GFP}^{+}$subpopulation of satellite cells was transplanted, showed that haploinsufficiency of $M y f 5$ affected the frequency of selfrenewed cells (Fig. 4D; $P<0.001$ ). To determine whether the regenerative potential was proportional to the number of cells injected, similar experiments were done with five times fewer transplanted cells (2000 cells instead of $10^{4}$ cells, Table 1). For both donor populations, about half the number of PLAP $^{+}$ myofibres and four times fewer satellite cells were obtained. Thus, contribution to the number of regenerating myofibres by the injected cells was not proportional to the number of cells injected, suggesting that a limited number of cells is required for myofibre contribution, and this could also be limited by the extent to which satellite cells can migrate. Notably, also in these experiments, more self-renewing cells were observed with $M y f 5$ heterozygous transplanted satellite cells compared with the wildtype control (Table 1).

\section{Long term self-renewal capacity of Myf5 heterozygous and Tg:Pax7-nGFP satellite cells}

To evaluate the capacity of Myf5 heterozygous and Tg:Pax7$n G F P$ satellite cells to self-renew after a second round of stem cell mobilisation, 3 weeks after the initial transplantation, the TA muscle was re-injured with notexin to provoke myofibre destruction and to trigger satellite cell activation. Neonatal myosin heavy chain (nMyHC), which marks regenerating myofibres (Collins et al., 2005), was co-expressed with PLAP, indicating that muscle regeneration took place after the notexin injury (Fig. 5A). Large areas of $\mathrm{PLAP}^{+}$myofibres were observed after the reinjury (Fig. 5Ba,b), and their quantification showed an equivalent number of $\mathrm{PLAP}^{+}$myofibres for $M y f 5^{G F P-P /+} / T$ and Tg:Pax7-nGFP/T ( $P>0.05$; Fig. 5C). Quantification of $\mathrm{GFP}^{+}$ satellite cells associated with $\mathrm{PLAP}^{+}$myofibres, showed more $\mathrm{GFP}^{+}$cells per section with $M y f 5^{G F P-P /+} / T$ compared with Tg:Pax7-nGFP/T (Fig. 5D; $P>0.01, n=5$ mice). Therefore, Myf5 heterozygous satellite cells continue to contribute robustly to muscle repair, and they yield more $\mathrm{GFP}^{+}$satellite cells compared with wild-type satellite cells.

\section{Discussion}

How stem cells regulate the balance between self-renewal and differentiation is a central question in stem cell biology. A variety of experimental approaches are used as readouts to assess these endpoints, such as cell transplantation and niche occupancy, as well as determination of the cell state using molecular readouts (Claudinot et al., 2005; Collins et al., 2007; Enver et al., 2009; Osawa et al., 1996; Sacco et al., 2008; Snippert and Clevers, 2011; Van Keymeulen et al., 2011). Skeletal muscle stem cells provide a model to address these questions, because the stem cell entity can be readily isolated and manipulated. Similar to many other tissues, however, the extent of heterogeneity in this population, and its functional relevance is not clear. To investigate these questions, we used genetic tools that permit a detailed phenotypic analysis of muscle stem cells. We present evidence that the levels of a determination gene Myf5 impact on muscle stem cell behaviour, and unexpectedly, with divergent phenotypic consequences depending on the assay employed to examine stem cell potential for commitment and self-renewal.

Although satellite cells play a crucial role in muscle growth and repair, outstanding questions remain regarding how 


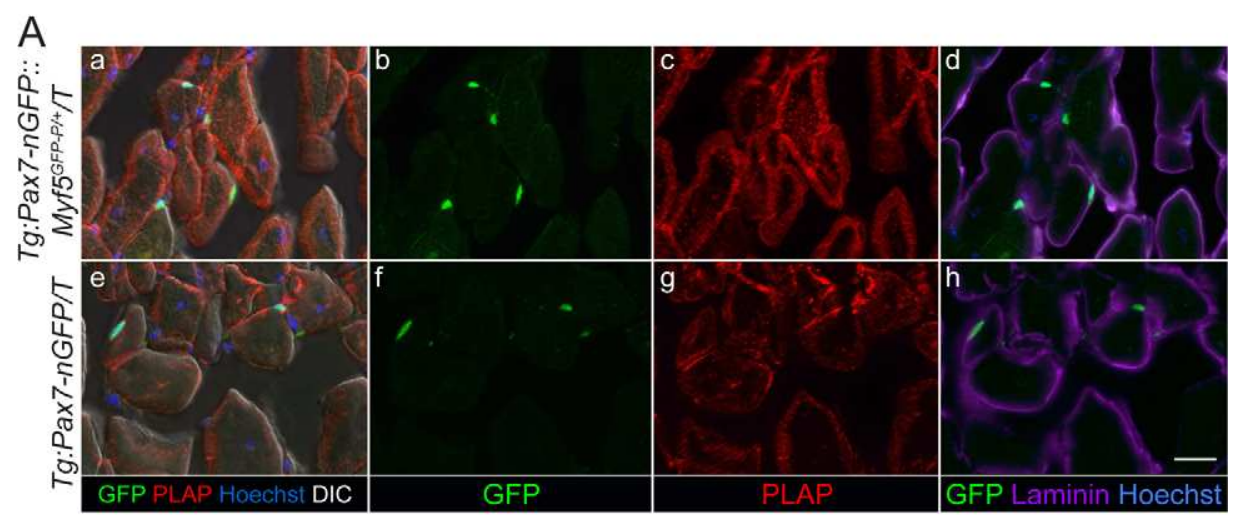

B

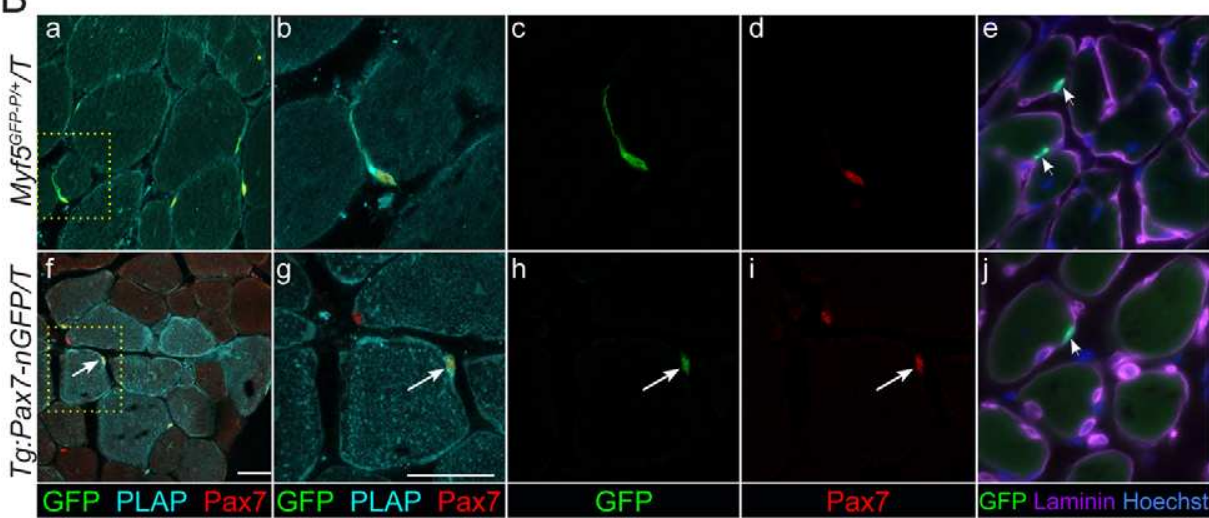

C
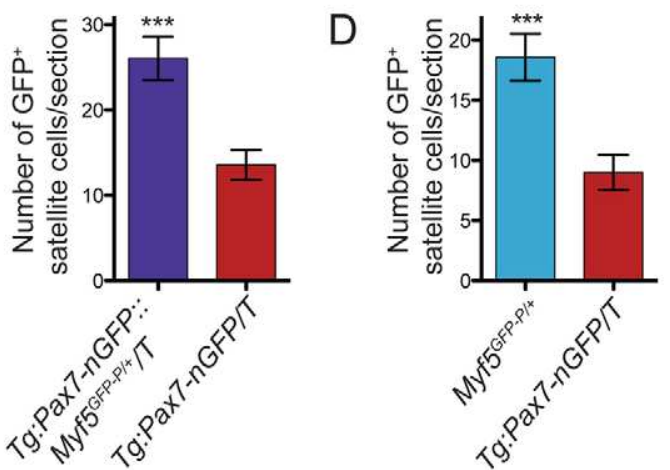

Fig. 4. Higher self-renewal capacity of transplanted $M y f 5^{G F P /+}$ satellite cells. (A) Immunostaining on cryosections of transplanted TA muscle showing PLAP ${ }^{+} \mathrm{GFP}^{+}$ engrafted satellite cells from $\mathrm{Tg}$ :Pax $7-$ $n G F P:: M y f 5^{G F P-P /+} / T(\mathrm{a}-\mathrm{d})$ and $T g: P a x 7-n G F P /$ $T(\mathrm{e}-\mathrm{h})$ located in the periphery of newly formed PLAP $^{+}$myotubes. $\mathrm{GFP}^{+}$cells are located under the laminin ${ }^{+}$basement membrane $(\mathrm{d}, \mathrm{h})$. (B) Immunostaining of cryosections of transplanted TA muscle showing $\mathrm{PLAP}^{+} \mathrm{GFP}^{+}$ engrafted satellite cells from $M y f 5^{G F P-P /+} / T$ (a-e) and $T g: P a x 7-n G F P / T(\mathrm{f}-\mathrm{j})$ located in the periphery of newly formed PLAP $^{+}$myofibres. $(a, f)$ Low magnification of representative areas of $\mathrm{PLAP}^{+}$regenerated myofibres. (b-d, g-i) High magnification of PLAP $^{+}$myofibres with $\mathrm{Pax}^{+} \mathrm{GFP}^{+}$associated satellite cells (arrows). $\mathrm{GFP}^{+}$cells are located under the laminin basement membrane (e, j; arrowheads). (C) Quantification of $\mathrm{GFP}^{+}$cells 4 weeks after engraftment represented as mean number of $\mathrm{GFP}^{+}$cells enumerated for all sections (Tg:Pax7$n G F P:: M y f 5^{G F P-P /+} / T ; n=4$ animals, 24 sections; Tg:Pax7-nGFP/T; $n=4$ animals, 24 sections). ${ }^{* * *} P<0.001$. (D) Quantification of $\mathrm{GFP}^{+}$cells 4 weeks after engraftment represented as mean number of $\mathrm{GFP}^{+}$cells enumerated for all sections $\left(M y f 5^{G F P-P /+} / T ; n=4\right.$ animals, 43 sections; Tg:Pax7- $n G F P / T ; n=4$ animals, 35 sections). ${ }^{* * *} P<0.001$. Scale bar: $20 \mu \mathrm{m}(\mathrm{A}, \mathrm{B})$. heterogeneities reported in this population (Beauchamp et al., 2000; Cerletti et al., 2008; Collins et al., 2005; Ieronimakis et al., 2010; Kuang et al., 2007; Montarras et al., 2005; Ono et al., 2010; Tanaka et al., 2009) correlate with self-renewal and commitment decisions. The two genetic models characterised here, heterozygous $\operatorname{Pax} 7^{n G F P /+}$ and transgenic Tg:Pax7-nGFP mice, faithfully recapitulate the expression of the endogenous $\operatorname{Pax} 7$ gene and express cell surface markers reported previously
(Bosnakovski et al., 2008; Kuang et al., 2007; Montarras et al., 2005). Interestingly, unlike $M y f 5$, heterozygosity of $\operatorname{Pax} 7$ did not show notable differences with wild-type stem cells by transcriptome analysis. This was unexpected given that haploinsufficiency has been noted for the paralogue of Pax7, Pax3, at least in neural crest derivatives (Goulding et al., 1991).

Genetic studies have underscored the importance of threshold levels of the crucial myogenic determination factors in the

Table 1. Comparative engraftment of 2000 and $\mathbf{1 0 , 0 0 0}$ cells injected in pre-injured TA muscle

\begin{tabular}{|c|c|c|c|c|c|c|}
\hline & \multicolumn{3}{|c|}{$\begin{array}{l}\text { Injection of } 2000 \text { cells } \\
\qquad(n=3 \text { mice })\end{array}$} & \multicolumn{3}{|c|}{$\begin{array}{l}\text { Injection of } 10,000 \text { cells } \\
(n=4 \text { mice })\end{array}$} \\
\hline & $M y f 5^{G F P-P /+} / T$ & $\operatorname{Pax} 7-n G F P / T$ & $P$ value & $M y f 5^{G F P-P /+} / T$ & $P a x 7-n G F P / T$ & $P$ value \\
\hline Max. number of PLAP ${ }^{+}$myofibres & $226 \pm 91$ & $122 \pm 24$ & $>0.05$ & $401 \pm 145$ & $293 \pm 86$ & $>0.05$ \\
\hline Mean number of $\mathrm{GFP}^{+}$satellite cells per section* & $4.7 \pm 0.94$ & $2.1 \pm 0.39$ & 0.01 & $18.5 \pm 1.96$ & $9 \pm 1.46$ & $<0.001$ \\
\hline Range of max. number of PLAP ${ }^{+}$myofibres per animal & $55-366$ & $95-172$ & & $90-690$ & $177-548$ & \\
\hline
\end{tabular}



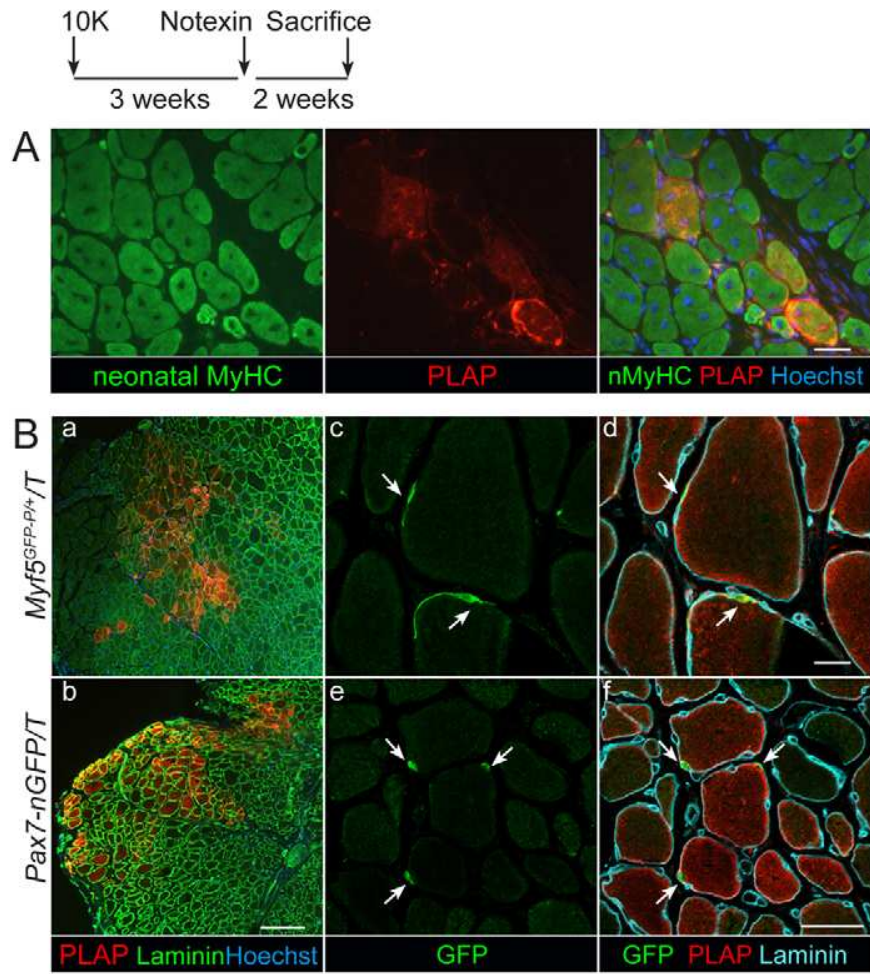

C
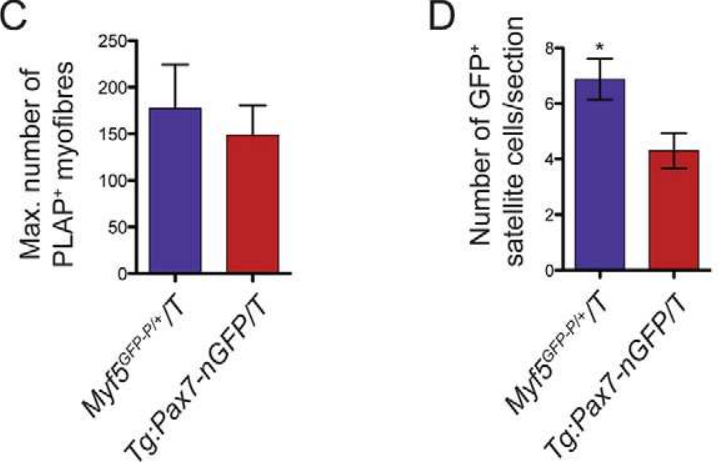

Fig. 5. Higher self-renewal capacity of $M y f 5$ heterozygous satellite cells after second cycle of regeneration. (A) Neonatal myosin heavy chain (nMyHC) staining indicates newly regenerated myofibres from PLAP $^{+}$ engrafted cells $\left(M y f 5^{G F P-P /+} / T\right)$. (B) Immunostaining for PLAP, laminin and GFP shows myofibres (a,b) and associated satellite cells (c-f; arrows), generated by engrafted satellite cells. (C) Quantification of PLAP ${ }^{+}$myofibres 14 days after reinjury with notexin in TA engrafted with $M y f 5^{G F P-P /+} / T(n=5$ recipient mice) and $T g: P a x 7-n G F P / T$ ( $n=5$ recipient mice). $P>0.05$.

(D) Quantification of $\mathrm{GFP}^{+}$satellite cells after notexin reinjury. Engrafted satellite cells from $M y f 5^{G F P-P /+} / T$ ( $n=5$ recipient mice, 55 sections) and Tg:Pax7-nGFP/T ( $n=5$ recipient mice, 46 sections) mice scored as $\mathrm{GFP}^{+} \mathrm{PLAP}^{+}$. Higher potential of $M y f 5^{G F P-P /+} / T$ cells to self-renew after notexin reinjury. ${ }^{*} P>0.01$. Results are mean \pm s.e.m. Scale bars: $200 \mu \mathrm{m}$ (A,B).

regulation of cell fate during prenatal development (KassarDuchossoy et al., 2004; Rudnicki et al., 1993; Weintraub, 1993). However, the role of these genes in quiescent adult stem cells remained unknown. We report the unexpected finding that muscle stem cells respond differentially to Myf5 for cell commitment, because heterozygous cells, either as a subpopulation from $M y f 5^{G F P-P}$ reporter mice, or the entire population, are more primed for myogenic commitment compared with total wild-type muscle stem cells. An additional unexpected outcome from our study was the observation that in spite of their more transcriptionally committed state, Myf5 heterozygous satellite cells assume a more stem-like phenotype after transplantation, because they show a higher frequency of self-renewal and niche occupancy. These findings indicate that for self-renewal after engraftment, the dose of Myf5 protein is crucial for modulating this cell state, because it is biased towards a stem-like phenotype in the heterozygous situation. Similar results were obtained after a second round of injury where engrafted donor muscle stem cells are mobilised from their niche to effect tissue repair, and subsequently self-renewing once again during homeostasis. Interestingly, this does not affect their ability to generate new myofibres. Consistent with these findings, Myf5null muscle stem cells have a higher self-renewal and niche occupancy capacity than wild-type stem cells; however, their ability to generate differentiated myofibres is reduced (B.G.M. and S.T., unpublished observations). These observations underscore the importance of the cell fate regulator Myf5 in modulating the balance between self-renewal and commitment. They also highlight unexpected differences in stem cell fate potential depending on the assay used, as was demonstrated recently for mammary stem cells (Van Keymeulen et al., 2011).

In differentiated cultures of the transformed muscle cell line $\mathrm{C} 2 \mathrm{C} 12$, Myf5 protein is observed in mononucleated reserve cells, which share some characteristics with satellite cells, including cellular quiescence, loss of Myod, and expression of Pax7 (Kitzmann et al., 1998; Yoshida et al., 1998). However, the expression of Myf5 protein in quiescent satellite cells had not been examined in detail and it has been debated extensively (Dhawan and Rando, 2005; Kuang et al., 2008; Tajbakhsh and Gonzalez, 2009; Zammit et al., 2002; Zammit et al., 2006). In the present study, western blot and immunolabelling on tissue section and myofibres showed that Myf5 protein is present in the majority of quiescent satellite cells, unlike the other MRFs. By contrast, Myod and myogenin proteins are detected in only a subset (7-11\% and $1 \%$, respectively) of quiescent satellite cells (Beauchamp et al., 2000; Fukada et al., 2007; Zammit et al., 2002) (data not shown). The third muscle determination factor Mrf4 is absent during quiescence, and it is expressed after differentiation (Gayraud-Morel et al., 2007). These observations can now be considered in light of the present findings, where we show that reducing the gene dose of Myf5 to heterozygous levels in quiescent satellite cells promoted the transcriptional upregulation of commitment genes. Moreover, Myf5 expression is markedly downregulated during differentiation (Beauchamp et al., 2000), and cells triple mutant for Myf5, Mrf4 and Myog do not differentiate (Valdez et al., 2000). The duality in the functional role of Myf5, as a promoter of muscle fate, and also as incompatible with differentiation, raises questions on the precise role of this transcription factor during different cell states in a myogenic lineage progression. Our findings with endogenous Myf5 heterozygous quiescent satellite cells indicates that Myf5 protein expression maintains the 'stemness' state, and lowering the levels of this cell fate determinant genetically results in a myogenic commitment phenotype in this cell state. It appears that its role is distinct in activated satellite cells as the levels of Myf5 protein increase dramatically in the transit amplifying myoblast population.

Interestingly, the number of satellite cells negative for Myf5 protein is in the same range as that reported for $\mathrm{YFP}^{-}$cells in a 
previous study ( $\leq 10 \%$ ) obtained by crossing Myf $5^{\text {cre }}$ mice with Rosa ${ }^{S T O P-Y F P}$ (Kuang et al., 2007). After satellite cell activation, Myf5 expression is upregulated and it is co-expressed with Pax7 and Myod. Notably, some quiescent and activated cells remain unstained for Myf5 protein (data not shown) as reported also using Myf5 $5^{\text {nlacZ/+ }}$ mice (Cooper et al., 1999). Taken together, satellite cell heterogeneity is clearly suggested by numerous studies, yet the mechanisms responsible for this heterogeneity have remained elusive. We show here that heterozygous levels of Myf5 can have an impact on cell fate for self-renewal, but not for cell commitment. One possibility is that cell fate decisions are deterministic and influenced by Myf5 protein levels when additional environmental cues are favourable for myogenic commitment. Another possibility is that all satellite cells exist in a state of flux with respect to the levels of this transcription factor, and cell fate decisions to commit or self-renew are decided stochastically. It is likely that in both scenarios, the level of Myf5 protein is a nodal point for how this decision is executed, as is suggested by our findings.

Other studies have shown that the level of Nanog transcription factor in ES cells is crucial for determining the state of the cell, either for favouring pluripotency (Nanog-high) or commitment (Nanog-low) (Chambers et al., 2007). In another study, the Scal receptor in a blood cell line was used to show the stochastic behaviour of cells and fluctuations of the expression of this gene at a population level. Interestingly, a Gaussian distribution of expression of Scal was re-established irrespective of the levels of expression of the isolated starting population (Chang et al., 2008). These and other studies looking at Pax6 in eye development and aniridia (Hill et al., 1991), Tbx1 in pharyngeal arch arteries and in DiGeorge syndrome (Lindsay et al., 2001), Tcf4 in CNS and Pitt-Hopkins Syndrome (Brockschmidt et al., 2007), or RUNX2 in osteoprogenitors and cleidocranial dysplasia (Cohen, 2009) have highlighted the notion that cell fates are assumed based on the expression levels of crucial factors when the opportunity arises. We propose that this is the case for Myf5 protein levels in quiescent muscle stem cells.

Previous studies showed that the number of satellite cells was not altered significantly in mice heterozygous or null for Myf5 up to 1 year of age, both in vitro and in vivo (Gayraud-Morel et al., 2007, Ustanina et al., 2007), indicating that the self-renewal and commitment decisions that are reported here are not due to overt alterations in cellular proliferation. Although a germ line null mutation in Myod results in twice as many myogenic cells in vivo (Gayraud-Morel et al., 2007; Macharia et al., 2010), their selfrenewal capacity after transplantation remains to be determined. Other factors that can affect regeneration efficiency are the type of injury model used (Gayraud-Morel et al., 2009), the number of transplanted cells, because fewer transplanted cells yield proportionally more self-renewing and differentiated cells, and the donor and recipient mouse strains used (Collins et al., 2005; Gross et al., 1999).

A recent study reported that satellite cell self-renewal is regulated by FGF (Shea et al., 2010) and Bmp (Wang et al., 2010) signalling, as well as the Angiopoietin receptor Tie2. Notably, less satellite cell self-renewal was reported in the absence of Tie2 (Abou-Khalil et al., 2009). Our study is in keeping with this observation because the levels of the Tie2 receptor, and its ligand Angiopoietin 1, were elevated in Myf5 heterozygous satellite cells, which is consistent with their tendency to self-renew more efficiently.
In summary, our findings point to a crucial role for Myf5 in regulating muscle stem cell self-renewal after transplantation during regeneration, in spite of their capacity to assume a more committed state in the resident niche. These observations point to unexpected opposing phenotypes that underlie the flexibility in the muscle stem cell state, and they suggest that Myf5 is a key modulator of these cell states. As such, they provide insights into how self-renewal and differentiation are differentially modulated in muscle stem cells.

\section{Materials and Methods}

\section{Ethics statement}

All animal work was performed according to national and European guidelines.

\section{Mice}

$M y f 5^{\text {GFP-P }}, M y f 5^{\text {loxP }}$ and $M y f 5^{\text {nlac }}$ were described earlier (Kassar-Duchossoy et al., 2004; Tajbakhsh et al., 1996). Briefly, Myf $5^{\text {nlac }}$ and $M y f 5^{\text {GFP-P }}$ comprise a 122 amino acid deletion in exon 1 and thus lack the bHLH domain. The $M y f 5^{l o x P}$ allele contains about $124 \mathrm{bp}$ in the first exon of Myf5 and this insertion does not affect Mrf4 expression in muscle progenitors in the embryo (Kassar-Duchossoy et al., 2004). For the transgenic Pax7-nGFP reporter mice, Tg:Pax7-nGFP, a BAC containing approximately $200 \mathrm{kbp}$ of mouse genomic DNA including the locus encoding $\operatorname{Pax} 7$ and sequences both upstream $(\sim 55 \mathrm{kbp}$ with respect to $\operatorname{Pax} 7$ initiator ATG) and downstream $(\sim 60 \mathrm{kbp}$ from terminator codon) was recombined in $E$. coli with a nuclear-localised EGFP (nGFP). The targeting vector was designed to introduce $n G F P$ into the first exon of the $\operatorname{Pax} 7$ gene (Sambasivan et al., 2009). The $\operatorname{Pax} 7^{n G F P}$ mouse was derived from a parental $P a x 7^{n G F P-P u r o}$ nlacZ knock-in mouse (nlacZ flanked by frt sites) that was crossed with a universal Flippase deleter mouse to place the $n G F P$ reporter gene in the first exon of $\operatorname{Pax} 7$ (R.S. and S.T., unpublished results). To isolate pure populations of satellite cells, based on GFP epifluorescence by FACS, Myf $5^{\text {loxP/+ }}$, $M y f 5^{G F P-P /+}$ and $M y f 5^{\text {nlacZ } /+}$ were crossed to $T g: P a x 7-n G F P$. To permanently mark engrafted cells, Myf5 and Pax7 reporter mice were crossed to the Tg:CAG-hPLAP carrying the human placental alkaline phosphatase gene that is expressed ubiquitously (DePrimo et al., 1996); and to the Tg:MLC3F-nlacZ-2E, which marks differentiated myonuclei (Kelly et al., 1995). For simplicity, mice carrying three to four genetic modifications, for example, Myf5 ${ }^{G F P-P}: \because T g: C A G-h P L A P \quad: \because T g: M L C 3 F-n l a c Z-2 E$ or Tg::Pax7-nGFP ::Myf5 ${ }^{G F P-P}:: T g: C A G-h P L A P$ ::Tg:MLC3F-nlacZ-2E or Tg:Pax7nGFP::Tg:CAG-hPLAP $\because: T g: M L C 3 F-n l a c Z-2 E$, are indicated as $M y f 5^{G F P-P} / T$, Tg:Pax 7-nGFP::Myf5 ${ }^{G F P-P} / T$ or Tg:Pax7-nGFP/T (T, Triple). Engraftment experiments were performed with immunocompromised $\mathrm{Rag}^{-1-}: \mathrm{C}^{-\gamma}$ recipient mice (Colucci et al., 1999).

\section{Satellite cell preparation and fluorescence-activated cell sorting and cytometry}

Satellite cells were prepared from mouse hindlimb and forelimb muscles. After removal of the major tendons, nerves and adipose tissue, muscle tissue was minced with scissors, then digested with a mixture of $0.1 \%$ collagenase $\mathrm{D}$ (Roche) and $0.2 \%$ trypsin (Invitrogen) in DMEM (Invitrogen) for five consecutive cycles of 25 minutes at $37^{\circ} \mathrm{C}$. For each round, the supernatant was filtered through a 100 and then $70 \mu \mathrm{m}$ cell strainer and trypsin was blocked with 10\% FBS (Invitrogen) on ice. Pooled supernatants from each digestion cycle were centrifuged at $515 \boldsymbol{g}$ for 15 minutes at $4{ }^{\circ} \mathrm{C}$. Pellets were washed at least four times with cold DMEM. Immediately before FACS, the cell suspension was filtered through a $40 \mu \mathrm{m}$ cell strainer and resuspended in 2\% FCS-DMEM. When necessary, propidium iodide was added at $1 \mu \mathrm{M}$ final concentration to eliminate dead cells during sorting. Isolation of cells was performed on a FACSAria (BD Biosciences) or Moflow (Beckman Coulter) FACS machine. Satellite cells for single-cell clonal analysis were sorted directly into 96-well plates with a $100 \mu \mathrm{M}$ nozzle on the FACSAria. For cytometry, single-cell suspension from muscle extract was incubated for 30 minutes on ice, with fluorescent primary antibodies (supplementary material Table S1), washed once with PBS and analysed by flow cytometry (CyAn, Beckman Coulter). Quadrants were established by the negative threshold based on isotype controls. Data was analysed post-acquisition by FlowJo.

\section{Muscle injury and satellite cell transplantation}

Immunocompromised $\operatorname{Rag}^{-/-}: \gamma C^{-/}$mice were subjected to freeze injury 2 days before cell engraftment. Briefly, mice were anesthetised with $0.5 \%$ Imalgene and $2 \%$ Rompun. The TA muscle was frozen with three consecutive cycles of freezethawing by applying a liquid nitrogen cooled metallic rod. The skin was sutured and mice were kept on a warm plate until recovery. Satellite cells collected by FACS were centrifuged for 15 minutes in an Eppendorf centrifuge at $550 \mathrm{~g}$. The supernatant was carefully eliminated and the pellet was resuspended in a minimal volume to inject $5-10 \mu \mathrm{l}$ of cell suspension per TA. Cell suspensions were enumerated using a Malassez counting chamber to adjust the concentration of cells 
injected to 2000 or 10,000 satellite cells in pre-injured TA with a $10 \mu 1$ Hamilton syringe. Four weeks after transplantation, mice were sacrificed by cervical dislocation and the tissue analysed. For reinjury experiments, 3 weeks after the transplantation, the TA are injected with $10 \mu \mathrm{l}$ of notexin (Latoxan) and mice were sacrificed 14 days later for analysis.

\section{Immunofluorescence and X-gal staining}

The TA muscle was fixed in $1 \%$ paraformaldehyde and $0.1 \%$ Triton X-100 in PBS at $4{ }^{\circ} \mathrm{C}$ for 2 hours, followed by an overnight incubation in $15 \%$ sucrose at $4{ }^{\circ} \mathrm{C}$. The muscle was frozen in liquid nitrogen in OCT and processed essentially as described (Gayraud-Morel et al., 2007). Cryosections $(10 \mu \mathrm{M})$ were collected on Superfrost slides (Thermo Scientific). Sections were washed in PBS, incubated in $0.5 \%$ Triton X-100 in PBS for 5 minutes, washed with PBS and blocked with $10 \%$ heat-inactivated goat serum. Primary antibodies (see supplementary material Table S1) were incubated overnight at $4^{\circ} \mathrm{C}$. After three PBS washes, Alexa-Fluor- or Cy3-conjugated secondary antibodies were added for 2 hours at room temperature, followed by several PBS washes and mounting of slides in 25\% PBS and $75 \%$ glycerol. For Pax7 staining on frozen sections, the primary monoclonal antibody was incubated overnight in $0.5 \%$ Triton X-100 in PBS, which replaces the unmasking protocol described previously (Gayraud-Morel et al., 2007). Myoblasts and single fibres were immunostained as described (Gayraud-Morel et al., 2007) For X-Gal staining, frozen sections were rinsed with PBS and stained for 2 hours with X-gal solution (Tajbakhsh et al., 1997) at $37^{\circ} \mathrm{C}$. Pictures were taken with a Leica SPE confocal or Zeiss Observer microscope equipped with a Zeiss camera.

\section{Quantification of myofibres and engrafted satellite cells}

For quantification, the entire TA muscle was sectioned and at least four different evenly spaced sections were stained and used for $\mathrm{PLAP}^{+}$myofibre and GFP satellite cell enumerations after immunostaining. For myofibre quantification, the section with the maximum number of $\mathrm{PLAP}^{+}$myofibres counted was considered for each animal. Graphs display the mean for all animals tested. Quantification of the $\mathrm{GFP}^{+}$satellite cells were expressed as the average number of $\mathrm{GFP}^{+}$satellite cells counted in 3-4 cryosections obtained from four different levels in $n=4-5$ mice. Graphs display average values of all animals tested \pm s.e.m. Student's $t$-tes or Mann-Whitney tests were performed to evaluate the significance of the values $(* P<0.05, * * P<0.01, * * * P<0.001)$

\section{Single-fibre preparations and cell culture}

Single fibres were isolated as described previously (Zammit et al., 2002). Briefly, EDL muscles were dissected and treated for 1 hour with $0.1 \%$ collagenase (C0130, Sigma) at $37^{\circ} \mathrm{C}$. For time zero experiments, fibres were fixed for 510 minutes with $4 \%$ paraformaldehyde (PFA) in PBS at room temperature immediately after single-fibre isolation. When required, single myofibres were incubated for up to 72 hours in $20 \%$ FCS (Invitrogen) in DMEM (Invitrogen):MCDB201 (Sigma) (1:1) medium with penicillin and streptomycin For myoblast cultures, sorted cells were plated on Matrigel (BD Biosciences) coated dishes, and grown in medium containing $20 \%$ FCS (Invitrogen) and $2 \%$ Ultroser in DMEM (Invitrogen):MCDB201 (Sigma) (1:1) medium with penicillin and streptomycin.

\section{Quantitative real-time reverse transcription polymerase chain reaction} Extraction and preparation of RNA for QRT-PCR were performed as described previously (Jory et al., 2009). Briefly, total mRNA were extracted with the RNAeasy Micro Plus purification kit (Qiagen) from 10,000 to $100,000 \mathrm{GFP}^{+}$ satellite cells collected during FACS directly into the lysis buffer containing $1 \% \beta$ mercaptoethanol as suggested by the manufacturer. RNAs were processed for random-primed reverse transcription using Superscript II protocol of Invitrogen (Carlsbad, CA). cDNAs were analysed using powerSYBR Green Universal Mix or Taqman universal Master Mix. Primers are listed in supplementary material Table S2.

\section{Western blotting}

Satellite cells were collected in 10\% FCS in DMEM from the cell sorter and centrifuged for 10 minutes at $6000 \mathrm{~g}$ at $4^{\circ} \mathrm{C}$. The pellet was resuspended in a minimal volume of lysis buffer ( $5 \mathrm{mM}$ EDTA, $50 \mathrm{mM}$ Tris- $\mathrm{HCl}, \mathrm{pH} 8,150 \mathrm{mM}$ $\mathrm{NaCl}, 0.5 \% \mathrm{NP} 40,0.1 \%$ SDS) with $2 \times$ protein inhibitor cocktail (Roche). Protein extracts were separated in 4-12\% Nu-Page precast gels (Invitrogen). After protein transfer [( $20 \%$ methanol, $80 \%$ Tris-glycine-SDS buffer (Bio-Rad)], the membrane was incubated with antibodies as described (Gayraud-Morel et al., 2007). To evaluate Myf5 content in quiescent and activated (3days in culture) cells, $5 \times 10^{4}$ cells were loaded per lane.

\section{GeneChip microarrays}

Briefly, satellite cell populations from $M y f 5^{G F P /+}$ and $\operatorname{Tg}: P a x 7-n G F P$, were collected from adult (6- to 8-week-old) mice based on GFP expression and isolation by FACS. RNA extraction was done using a Qiagen RNeasy Micro kit. cDNA obtained from $100 \mathrm{ng}$ of RNA was amplified by using the GeneChip
Expression Two-Cycle 3' amplification system (Affymetrix). Fragmented biotinlabelled cRNA samples were hybridized on GeneChip Mouse Genome 430_2 arrays (Affymetrix 430.2 .0 mouse array that contains 45000 probe sets). For each experimental group, three biological replicates were hybridized. The generation of cell intensity files and the quality control of hybridizations were performed with GeneChip Operating Software (Affymetrix). Raw data were pre-processed using the GC-Robust Multichip Analysis (GCRMA) algorithm in order to correct the background, to adjust the intensity distribution over the arrays and to convert probe intensity summarisation into a unique probe set signal. Local Pooled Error (Jain et al., 2003) tests were performed to identify significant differences in gene expression between groups. The Benjamini-Hochberg (Benjamini and Hochberg, 1995) multiple correction test was applied to control for the number of false positives with an adjusted 5\% statistical significance threshold. Unbiased analysis of comparative enrichment of functionally related gene ontology categories were performed using DAVID (Huang da et al., 2009). Selected candidates from two relevant enriched categories (skeletal muscle differentiation and development) are presented in this article.

\section{Acknowledgements}

We thank C. Cimper for technical assistance and M. Nguyen, P.-H Commere, A. Danckaert (PFC, PFID, Institut Pasteur, Paris), A. Henry and A. Guguin (IMRB, UFR de Medecine, Créteil) for cytometry and Béatrice Regnault for microarray data. We also thank G. Butler-Browne and members of the lab for critical comments and discussion.

\section{Funding}

We acknowledge support from the Institut Pasteur, Association Française contre le Myopathies, Agence Nationale de la Recherche, MyoRes (EU Framework 7 project EuroSysStem), Optistem and Fondation pour la Recherche Medicale.

Supplementary material available online at http://jcs.biologists.org/lookup/suppl/doi:10.1242/jcs.097006/-/DC1

\section{References}

Abou-Khalil, R., Le Grand, F., Pallafacchina, G., Valable, S., Authier, F. J., Rudnicki, M. A., Gherardi, R. K., Germain, S., Chretien, F., Sotiropoulos, A. et al. (2009). Autocrine and paracrine angiopoietin 1/Tie-2 signaling promotes muscle satellite cell self-renewal. Cell Stem Cell 5, 298-309.

Beauchamp, J. R., Heslop, L., Yu, D. S., Tajbakhsh, S., Kelly, R. G., Wernig, A. Buckingham, M. E., Partridge, T. A. and Zammit, P. S. (2000). Expression of CD34 and Myf5 defines the majority of quiescent adult skeletal muscle satellite cells. J. Cell Biol. 151, 1221-1234.

Benjamini, Y. and Hochberg, Y. (1995). Controlling the false discovery rate: A practical and powerful approach to multiple testing. J. R. Stat. Soc. 57, 289-300.

Bosnakovski, D., Xu, Z., Li, W., Thet, S., Cleaver, O., Perlingeiro, R. C. and Kyba, M. (2008). Prospective isolation of skeletal muscle stem cells with a Pax7 reporter. Stem Cells 26, 3194-3204.

Brockschmidt, A., Todt, U., Ryu, S., Hoischen, A., Landwehr, C., Birnbaum, S., Frenck, W., Radlwimmer, B., Lichter, P., Engels, H. et al. (2007). Severe mental retardation with breathing abnormalities (Pitt-Hopkins syndrome) is caused by haploinsufficiency of the neuronal bHLH transcription factor TCF4. Hum. Mol Genet. 16, 1488-1494.

Cerletti, M., Jurga, S., Witczak, C. A., Hirshman, M. F., Shadrach, J. L., Goodyear, L. J. and Wagers, A. J. (2008). Highly efficient, functional engraftment of skeletal muscle stem cells in dystrophic muscles. Cell 134, 37-47.

Chambers, I., Silva, J., Colby, D., Nichols, J., Nijmeijer, B., Robertson, M., Vrana, J., Jones, K., Grotewold, L. and Smith, A. (2007). Nanog safeguards pluripotency and mediates germline development. Nature 450, 1230-1234.

Chang, H. H., Hemberg, M., Barahona, M., Ingber, D. E. and Huang, S. (2008) Transcriptome-wide noise controls lineage choice in mammalian progenitor cells. Nature 453, 544-547.

Claudinot, S., Nicolas, M., Oshima, H., Rochat, A. and Barrandon, Y. (2005). Longterm renewal of hair follicles from clonogenic multipotent stem cells. Proc. Natl. Acad. Sci. USA 102, 14677-14682.

Cohen, M. M., Jr (2009). Perspectives on RUNX genes: an update. Am. J. Med. Genet. 149A, 2629-2646.

Collins, C. A., Olsen, I., Zammit, P. S., Heslop, L., Petrie, A., Partridge, T. A. and Morgan, J. E. (2005). Stem cell function, self-renewal, and behavioral heterogeneity of cells from the adult muscle satellite cell niche. Cell 122, 289-301.

Collins, C. A., Zammit, P. S., Ruiz, A. P., Morgan, J. E. and Partridge, T. A. (2007) A population of myogenic stem cells that survives skeletal muscle aging. Stem Cells 25, 885-894.

Colucci, F., Soudais, C., Rosmaraki, E., Vanes, L., Tybulewicz, V. L. and Di Santo, J. P. (1999). Dissecting NK cell development using a novel alymphoid mouse model: 
investigating the role of the c-abl proto-oncogene in murine NK cell differentiation. J. Immunol. 162, 2761-2765.

Conboy, I. M., Conboy, M. J., Smythe, G. M. and Rando, T. A. (2003). Notch-mediated restoration of regenerative potential to aged muscle. Science 302, 1575-1577.

Conboy, M. J., Karasov, A. O. and Rando, T. A. (2007). High incidence of nonrandom template strand segregation and asymmetric fate determination in dividing stem cells and their progeny. PLoS Biol. 5, e102.

Cooper, R. N., Tajbakhsh, S., Mouly, V., Cossu, G., Buckingham, M. and ButlerBrowne, G. S. (1999). In vivo satellite cell activation via Myf5 and MyoD in regenerating mouse skeletal muscle. J. Cell Sci. 112, 2895-2901.

Cornelison, D. D., Wilcox-Adelman, S. A., Goetinck, P. F., Rauvala, H., Rapraeger, A. C. and Olwin, B. B. (2004). Essential and separable roles for Syndecan-3 and Syndecan-4 in skeletal muscle development and regeneration. Genes. Dev. 18, 22312236

Day, K., Shefer, G., Shearer, A. and Yablonka-Reuveni, Z. (2010). The depletion of skeletal muscle satellite cells with age is concomitant with reduced capacity of single progenitors to produce reserve progeny. Dev. Biol. 340, 330-343.

Delfini, M. C., Hirsinger, E., Pourquie, O. and Duprez, D. (2000). Delta 1-activated notch inhibits muscle differentiation without affecting Myf5 and Pax3 expression in chick limb myogenesis. Development 127, 5213-5224.

DePrimo, S. E., Stambrook, P. J. and Stringer, J. R. (1996). Human placental alkaline phosphatase as a histochemical marker of gene expression in transgenic mice. Transgenic Res. 5, 459-466.

Dhawan, J. and Rando, T. A. (2005). Stem cells in postnatal myogenesis: molecular mechanisms of satellite cell quiescence, activation and replenishment. Trends Cell Biol. 15, 666-673.

Enver, T., Pera, M., Peterson, C. and Andrews, P. W. (2009). Stem cell states, fates, and the rules of attraction. Cell Stem Cell 4, 387-397.

Fukada, S., Uezumi, A., Ikemoto, M., Masuda, S., Segawa, M., Tanimura, N., Yamamoto, H., Miyagoe-Suzuki, Y. and Takeda, S. (2007). Molecular signature of quiescent satellite cells in adult skeletal muscle. Stem Cells 25, 2448-2459.

Gayraud-Morel, B., Chretien, F., Flamant, P., Gomes, D., Zammit, P. S. and Tajbakhsh, S. (2007). A role for the myogenic determination gene Myf5 in adult regenerative myogenesis. Dev. Biol. 312, 13-28.

Gayraud-Morel, B., Chretien, F. and Tajbakhsh, S. (2009). Skeletal muscle as a paradigm for regenerative biology and medicine. Regen. Med. 4, 293-319.

Gnocchi, V. F., White, R. B., Ono, Y., Ellis, J. A. and Zammit, P. S. (2009). Further characterisation of the molecular signature of quiescent and activated mouse muscle satellite cells. PLoS ONE 4, e5205.

Goulding, M. D., Chalepakis, G., Deutsch, U., Erselius, J. R. and Gruss, P. (1991) Pax-3, a novel murine DNA binding protein expressed during early neurogenesis. EMBO J. 10, 1135-1147

Gross, J. G., Bou-Gharios, G. and Morgan, J. E. (1999). Potentiation of myoblast transplantation by host muscle irradiation is dependent on the rate of radiation delivery. Cell Tissue Res. 298, 371-375.

Harel, I., Nathan, E., Tirosh-Finkel, L., Zigdon, H., Guimaraes-Camboa, N., Evans, S. M. and Tzahor, E. (2009). Distinct origins and genetic programs of head muscle satellite cells. Dev. Cell 16, 822-832.

Hasty, P., Bradley, A., Morris, J. H., Edmondson, D. G., Venuti, J. M., Olson, E. N. and Klein, W. H. (1993). Muscle deficiency and neonatal death in mice with a targeted mutation in the myogenin gene. Nature 364, 501-506.

Hill, R. E., Favor, J., Hogan, B. L., Ton, C. C., Saunders, G. F., Hanson, I. M., Prosser, J., Jordan, T., Hastie, N. D. and van Heyningen, V. (1991). Mouse small eye results from mutations in a paired-like homeobox-containing gene. Nature 354, $522-525$

Huang da, W., Sherman, B. T. and Lempicki, R. A. (2009). Systematic and integrative analysis of large gene lists using DAVID bioinformatics resources. Nat. Protoc. 4, 44-57.

Ieronimakis, N., Balasundaram, G., Rainey, S., Srirangam, K., Yablonka-Reuveni, Z. and Reyes, M. (2010). Absence of CD34 on murine skeletal muscle satellite cells marks a reversible state of activation during acute injury. PLOS ONE 5, e10920.

Jain, N., Thatte, J., Braciale, T., Ley, K., O'Connell, M. and Lee, J. K. (2003). Localpooled-error test for identifying differentially expressed genes with a small number of replicated microarrays. Bioinformatics 19, 1945-1951.

Joe, A. W., Yi, L., Natarajan, A., Le Grand, F., So, L., Wang, J., Rudnicki, M. A. and Rossi, F. M. (2010). Muscle injury activates resident fibro/adipogenic progenitors that facilitate myogenesis. Nat. Cell Biol. 12, 153-163.

Jory, A., Le Roux, I., Gayraud-Morel, B., Rocheteau, P., Cohen-Tannoudji, M., Cumano, A. and Tajbakhsh, S. (2009). Numb promotes an increase in skeletal muscle progenitor cells in the embryonic somite. Stem Cells 27, 2769-2780.

Kanisicak, O., Mendez, J. J., Yamamoto, S., Yamamoto, M. and Goldhamer, D. J. (2009). Progenitors of skeletal muscle satellite cells express the muscle determination gene, MyoD. Dev. Biol. 332, 131-141.

Kassar-Duchossoy, L., Gayraud-Morel, B., Gomès, D., Rocancourt, D., Buckingham, M., Shinin, V. and Tajbakhsh, S. (2004). Mrf4 determines skeletal muscle identity in Myf5:Myod double-mutant mice. Nature 431, 466-471.

Kelly, R., Alonso, S., Tajbakhsh, S., Cossu, G. and Buckingham, M. (1995). Myosin light chain $3 \mathrm{~F}$ regulatory sequences confer regionalised cardiac and skeletal muscle reporter gene expression in transgenic mice. J. Cell. Biol. 129, 383-396.

Kitzmann, M., Carnac, G., Vandromme, M., Primig, M., Lamb, N. J. and Fernandez, A. (1998). The muscle regulatory factors MyoD and myf-5 undergo distinct cell cycle-specific expression in muscle cells. J. Cell Biol. 142, 1447-1459.

Kuang, S. and Rudnicki, M. A. (2008). The emerging biology of satellite cells and their therapeutic potential. Trends Mol. Med. 14, 82-91.
Kuang, S., Charge, S. B., Seale, P., Huh, M. and Rudnicki, M. A. (2006). Distinct roles for Pax7 and Pax3 in adult regenerative myogenesis. J. Cell Biol. 172, 103-113.

Kuang, S., Kuroda, K., Le Grand, F. and Rudnicki, M. A. (2007). Asymmetric selfrenewal and commitment of satellite stem cells in muscle. Cell 129, 999-1010.

Kuang, S., Gillespie, M. A. and Rudnicki, M. A. (2008). Niche regulation of muscle satellite cell self-renewal and differentiation. Cell Stem Cell 2, 22-31.

Lagord, C., Soulet, L., Bonavaud, S., Bassaglia, Y., Rey, C., Barlovatz-Meimon, G., Gautron, J. and Martelly, I. (1998). Differential myogenicity of satellite cells isolated from extensor digitorum longus (EDL) and soleus rat muscles revealed in vitro. Cell Tissue Res. 291, 455-468.

Lepper, C., Conway, S. J. and Fan, C. M. (2009). Adult satellite cells and embryonic muscle progenitors have distinct genetic requirements. Nature 460, 627-631.

Li, L. and Clevers, H. (2010). Coexistence of quiescent and active adult stem cells in mammals. Science 327, 542-545.

Lindsay, E. A., Vitelli, F., Su, H., Morishima, M., Huynh, T., Pramparo, T., Jurecic, V., Ogunrinu, G., Sutherland, H. F., Scambler, P. J. et al. (2001). Tbx1 haploinsufficieny in the DiGeorge syndrome region causes aortic arch defects in mice. Nature 410, 97-101.

Lugert, S., Basak, O., Knuckles, P., Haussler, U., Fabel, K., Gotz, M., Haas, C. A., Kempermann, G., Taylor, V. and Giachino, C. (2010). Quiescent and active hippocampal neural stem cells with distinct morphologies respond selectively to physiological and pathological stimuli and aging. Cell Stem Cell 6, 445-456.

Macharia, R., Otto, A., Valasek, P. and Patel, K. (2010). Neuromuscular junction morphology, fiber-type proportions, and satellite-cell proliferation rates are altered in MyoD (-/-) mice. Muscle Nerve 42, 38-52.

Mitchell, K. J., Pannerec, A., Cadot, B., Parlakian, A., Besson, V., Gomes, E. R., Marazzi, G. and Sassoon, D. A. (2010). Identification and characterization of a nonsatellite cell muscle resident progenitor during postnatal development. Nat. Cell Biol. 12, 257-266.

Montarras, D., Morgan, J., Collins, C., Relaix, F., Zaffran, S., Cumano, A., Partridge, T. and Buckingham, M. (2005). Direct isolation of satellite cells for skeletal muscle regeneration. Science 309, 2064-2067.

Nabeshima, Y., Hanaoka, K., Hayasaka, M., Esumi, E., Li, S., Nonaka, I. and Nabeshima, Y. (1993). Myogenin gene disruption results in perinatal lethality because of severe muscle defect. Nature 364, 532-535.

Ono, Y., Boldrin, L., Knopp, P., Morgan, J. E. and Zammit, P. S. (2010). Muscle satellite cells are a functionally heterogeneous population in both somite-derived and branchiomeric muscles. Dev. Biol. 337, 29-41.

Osawa, M., Hanada, K., Hamada, H. and Nakauchi, H. (1996). Long-term lymphohematopoietic reconstitution by a single CD34-low/negative hematopoietic stem cell. Science 273, 242-245.

Oustanina, S., Hause, G. and Braun, T. (2004). Pax7 directs postnatal renewal and propagation of myogenic satellite cells but not their specification. EMBO. J. 23, 34303439.

Relaix, F., Rocancourt, D., Mansouri, A. and Buckingham, M. (2005). A Pax3/Pax7dependent population of skeletal muscle progenitor cells. Nature 435, 948-953.

Relaix, F., Montarras, D., Zaffran, S., Gayraud-Morel, B., Rocancourt, D., Tajbakhsh, S., Mansouri, A., Cumano, A. and Buckingham, M. (2006). Pax3 and Pax7 have distinct and overlapping functions in adult muscle progenitor cells. J. Cell Biol. 172, 91-102.

Rocheteau, P., Gayraud-Morel, B., Siegl-Cachedenier, I., Blasco, M. A. and Tajbakhsh, S. (2012). A subpopulation of adult skeletal muscle stem cells retains all template DNA strands after cell division. Cell 148, 112-125.

Rudnicki, M. A., Schnegelsberg, P. N., Stead, R. H., Braun, T., Arnold, H. H. and Jaenisch, R. (1993). MyoD or Myf-5 is required for the formation of skeletal muscle. Cell 75, 1351-1359.

Sacco, A., Doyonnas, R., Kraft, P., Vitorovic, S. and Blau, H. M. (2008). Self-renewal and expansion of single transplanted muscle stem cells. Nature 456, 502-506.

Sambasivan, R., Gayraud-Morel, B., Dumas, G., Cimper, C., Paisant, S., Kelly, R. G. and Tajbakhsh, S. (2009). Distinct regulatory cascades govern extraocular and pharyngeal arch muscle progenitor cell fates. Dev. Cell 16, 810-821.

Schultz, E., Albright, D. J., Jaryszak, D. L. and David, T. L. (1988). Survival of satellite cells in whole muscle transplants. Anat. Rec. 222, 12-17.

Schuster-Gossler, K., Cordes, R. and Gossler, A. (2007). Premature myogenic differentiation and depletion of progenitor cells cause severe muscle hypotrophy in Delta1 mutants. Proc. Natl. Acad. Sci. USA 104, 537-542.

Seale, P., Sabourin, L. A., Girgis-Gabardo, A., Mansouri, A., Gruss, P. and Rudnicki, M. A. (2000). Pax7 is required for the specification of myogenic satellite cells. Cell 102, 777-786.

Shea, K. L., Xiang, W., LaPorta, V. S., Licht, J. D., Keller, C., Basson, M. A. and Brack, A. S. (2010). Sprouty1 regulates reversible quiescence of a self-renewing adult muscle stem cell pool during regeneration. Cell Stem Cell 6, 117-129.

Shinin, V., Gayraud-Morel, B., Gomes, D. and Tajbakhsh, S. (2006). Asymmetric division and cosegregation of template DNA strands in adult muscle satellite cells. Nat. Cell Biol. 8, 677-682.

Silva-Barbosa, S. D., Butler-Browne, G. S., Di Santo, J. P. and Mouly, V. (2005). Comparative analysis of genetically engineered immunodeficient mouse strains as recipients for human myoblast transplantation. Cell Transplant. 14, 457-467.

Snippert, H. J. and Clevers, H. (2011). Tracking adult stem cells. EMBO. Rep. 12, 113-122.

Sun, D., Li, H. and Zolkiewska, A. (2008). The role of Delta-like 1 shedding in muscle cell self-renewal and differentiation. J. Cell Sci. 121, 3815-3823.

Tajbakhsh, S. (2009). Skeletal muscle stem cells in developmental versus regenerative myogenesis. J. Intern. Med. 266, 372-389. 
Tajbakhsh, S. and Gonzalez, C. (2009). Biased segregation of DNA and centrosomes: moving together or drifting apart? Nat. Rev. Mol. Cell Biol. 10, 804-810.

Tajbakhsh, S., Rocancourt, D. and Buckingham, M. (1996). Muscle progenitor cells failing to respond to positional cues adopt non-myogenic fates in myf-5 null mice. Nature 384, 266-270.

Tajbakhsh, S., Rocancourt, D., Cossu, G. and Buckingham, M. (1997). Redefining the genetic hierarchies controlling skeletal myogenesis: $P a x-3$ and $M y f-5$ act upstream of MyoD. Cell 89, 127-138.

Tanaka, K. K., Hall, J. K., Troy, A. A., Cornelison, D. D., Majka, S. M. and Olwin, B. B. (2009). Syndecan-4-expressing muscle progenitor cells in the SP engraft as satellite cells during muscle regeneration. Cell Stem Cell 4, 217-225.

Ustanina, S., Carvajal, J., Rigby, P. and Braun, T. (2007). The myogenic factor Myf5 supports efficient skeletal muscle regeneration by enabling transient myoblast amplification. Stem Cells 25, 2006-2016.

Valdez, M. R., Richardson, J. A., Klein, W. H. and Olson, E. N. (2000). Failure of Myf5 to support myogenic differentiation without myogenin, MyoD, and MRF4. Dev Biol. 219, 287-298.

Van Keymeulen, A., Rocha, A. S., Ousset, M., Beck, B., Bouvencourt, G., Rock, J., Sharma, N., Dekoninck, S. and Blanpain, C. (2011). Distinct stem cells contribute to mammary gland development and maintenance. Nature 479, 189-195.

Waddell, J. N., Zhang, P., Wen, Y., Gupta, S. K., Yevtodiyenko, A., Schmidt, J. V., Bidwell, C. A., Kumar, A. and Kuang, S. (2010). Dlk1 is necessary for proper skeletal muscle development and regeneration. PLOS ONE 5, e15055.
Wang, H., Noulet, F., Edom-Vovard, F., Tozer, S., Le Grand, F. and Duprez, D. (2010). Bmp signaling at the tips of skeletal muscles regulates the number of fetal muscle progenitors and satellite cells during development. Dev. Cell 18, 643-654.

Weintraub, H. (1993). The MyoD family and myogenesis: redundancy, networks, and thresholds. Cell 75, 1241-1244.

Wilson, A., Laurenti, E., Oser, G., van der Wath, R. C., Blanco-Bose, W., Jaworski, M., Offner, S., Dunant, C. F., Eshkind, L., Bockamp, E. et al. (2008). Hematopoietic stem cells reversibly switch from dormancy to self-renewal during homeostasis and repair. Cell 135, 1118-1129.

Yoshida, N., Yoshida, S., Koishi, K., Masuda, K. and Nabeshima, Y. (1998). Cell heterogeneity upon myogenic differentiation: down-regulation of MyoD and Myf-5 generates 'reserve cells'. J. Cell Sci. 111, 769-779.

Zammit, P. S., Heslop, L., Hudon, V., Rosenblatt, J. D., Tajbakhsh, S., Buckingham, M. E., Beauchamp, J. R. and Partridge, T. A. (2002). Kinetics of myoblast proliferation show that resident satellite cells are competent to fully regenerate skeletal muscle fibers. Exp. Cell Res. 281, 39-49.

Zammit, P. S., Golding, J. P., Nagata, Y., Hudon, V., Partridge, T. A. and Beauchamp, J. R. (2004). Muscle satellite cells adopt divergent fates: a mechanism for self-renewal? J. Cell Biol. 166, 347-357.

Zammit, P. S., Partridge, T. A. and Yablonka-Reuveni, Z. (2006). The skeletal muscle satellite cell: the stem cell that came in from the cold. J. Histochem. Cytochem. 54, 1177-1191. 